\title{
STRATIGRAPHIC ANALYSIS SYSTEM: SAS
}

\author{
BRIAN R. SHAW \\ Department of Geology, Syracuse University, Syracuse, NY 13210, U.S.A. \\ RICHARD SIMMS \\ Department of Computer Sciences, University of Michigan, Ann Arbor, MI 48104, U.S.A.
}

(Received 30 November 1976)

\begin{abstract}
Stratigraphic Analysis System (SAS) is an on-line, interactive data-base analysis system designed for use in a subsurface laboratory. The program is written in FORTRAN and ALGOL W and presently runs under the Michigan Terminal System at the University of Michigan.

The SAS system was designed to overcome several problems in geological data-base systems. Both data discontinuities and substring indexing have been considered as well as three-dimensional location of information.

The system consists of four procedures; the command processor, the user aid package, the data-set loader and general data processors. The data set is composed of hierarchical records in a one-dimensional array which consists of logical flags to index an internal dictionary.

Presently output contains well listings, well displays, data editing and data search capabilities.
\end{abstract}

Key Words: Stratigraphy, Data system, Subsurface geology.

\section{INTRODUCTION}

The design of a subsurface data-base system in geology must include features that take into account special constraints imposed by the nature of geological data.

Three initial problems of substring indexing, location assignment in three dimensions, and missing information are all factors that should be incorporated into a system design. Substring indexing is necessary due to the diverse nature of geologic data. The data set should contain lithologic, stratigraphic, and paleontologic data but not all of this information is used at any one time. It is necessary therefore to be able to index a portion of the information record. Geologic information is almost always (or always, for subsurface information) at a depth or elevation involving the assignment of information to a location in three-dimensional space. The last problem, that of missing information, is a difficult one to approach. There are two types of discontinuities; geologic and data imposed. The difference between them is crucial; one implies a lack of data due to geological processes, the other due to sampling difficulties. These must be clearly separated in the data set.

\section{SAS}

Stratigraphic Analysis System (SAS) is an on-line interactive computer information system designed to handle subsurface well data. The system allows the user to examine, modify, and manipulate a data set which is organized to reflect the described problems. SAS was intended for use at the University of Michigan Subsurface Laboratory and is based in part on portions of a stratigraphic analysis system developed by Mosher (1963).

SAS is written primarily in the ALGOL $W$ language, created by Stanford University as an extension of the ALGOL 60 language and modified by the University of Newcastle-Upon-Tyne to run under the Michigan Ter- minal System. The Michigan Terminal System (MTS) is a large resident, reentrant operating subsystem developed by the computing center staft at the University (Univ. Mich. Comp. Ctr., 1971, 1974). ALGOL W was chosen because it lends itself to structured programming. Inputoutput limitations in ALGOL W were supplemented by externally defined FORTRAN subroutines which allow SAS to use multiple logical input-output units.

The SAS program and its data set are kept on disk files and are run on the University of Michigan's AMDAHL $470 \mathrm{~V} / 6$ computer under the control of MTS in conversational mode from any terminal or teletype, or in nonconversational batch mode.

\section{PROGRAM STRUCTURE}

The SAS program is composed of several separate internally and externally defined ALGOL $W$ procedures and FORTRAN subroutines which each have a distinct function (Fig. 1). The most important procedures are the command processor, the user aid package, the data set loader, and the general data processors.

The command processor serves as the interface between the user and SAS. The command processor prompts the user to enter commands, checks the commands for syntactical validity, and then invokes the appropriate procedure to satisfy the command request. An invalid command causes the command processor to print an appropriate error message.

One of the special features of the SAS system is the user-aid package. The user-aid package serves the role of an on-line counsellor. It is easy for the user to forget some of the available commands and their functions, as well as becoming frustrated or confused. The user-aid package monitors the progress of the user. Upon request it will explain why a previous command was invalid, and it can produce a list of all avaliable commands as well as explain the function of a specific command. 


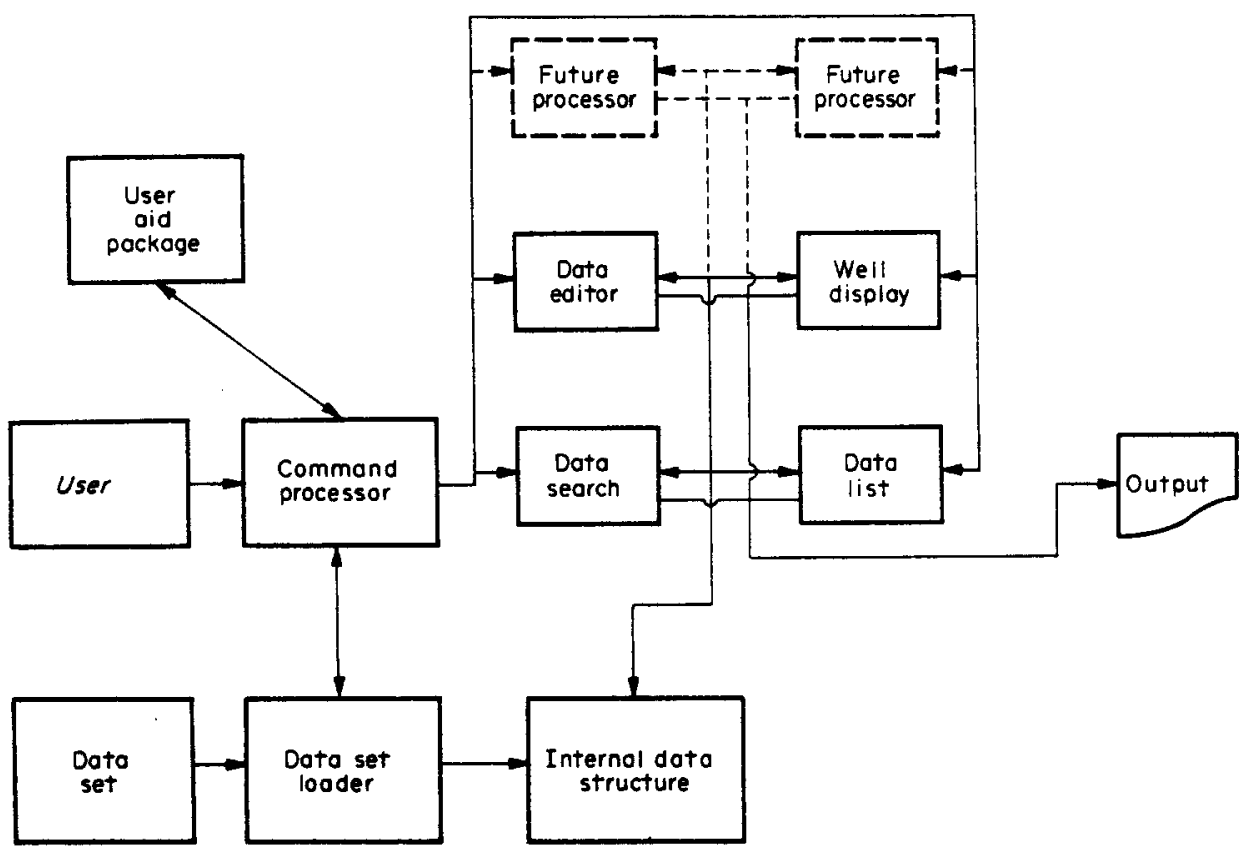

Figure 1. Basic structure of SAS

The data-set loader procedure which is invoked via the command processor, loads the subsurface data out of a disk file or a magnetic tape into central memory, where the data are indexed and linked together to provide rapid accessing times. Only part of the data set is in central memory at any given time as the computer employs a virtual memory system. Part of the data-set loader was written in FORTRAN to overcome ALGOL W's inability to read data from more than one logical input-output unit. The FORTRAN subroutines allow SAS to input information from the user's terminal as well as data and information from various disk files.

The data processors are general procedures that do the work of manipulating information in the data set. There are several processors with distinct functions, each invoked by appropriate commands to the command processor. There are processors currently to generate cross sections, well and stratigraphic interval listings, as well as procedures to scan and modify the data set. This part of the system is readily expandable. New procedures written in ALGOL W, FORTRAN, or any other language which employ standard IBM S-type linkages (Univ. Mich. Comp. Ctr., 1972) can be appended to the system with an appropriate command addition to the command processor.

\section{DATA SET}

The data set of SAS follows a convenient and flexible format which has several important features. The most important aspect of the data format is the telescoping of descriptive information into a specified interva! within a well as opposed to a stratigraphic 'top'.

A well can be separated into stratigraphic intervals (Fig. 2) which can be subdivided further into separate lithologic intervals. The data set reflects this natural subdivision of information in the form of three distinct

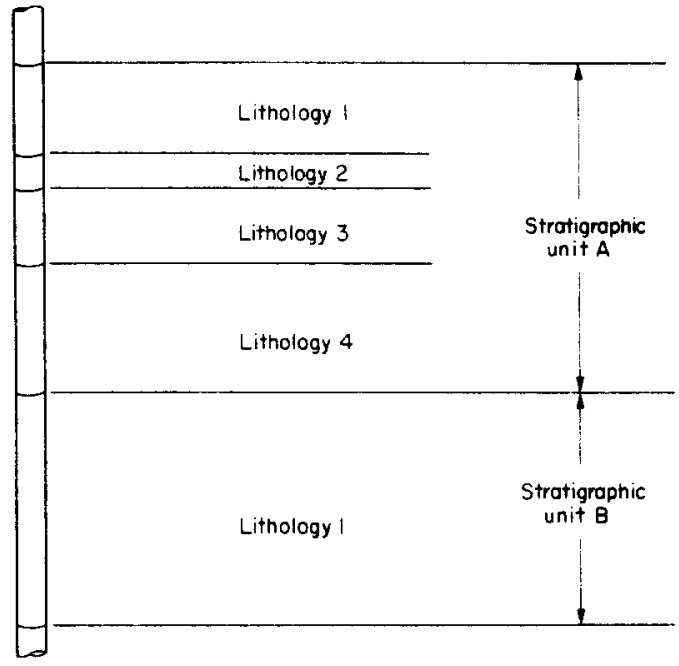

Figure 2. Interval assignment of information in SAS.

hierarchical types of records. In the data set a well is defined by: (1) a well ID record (Fig. 3), which contains data elements describing the name, number, location and elevation of the well; (2) stratigraphic records (Fig. 3) corresponding to each stratigraphic interval in the well; and (3) lithologic records (Fig. 4) to correspond to each lithologic interval within a stratigraphic interval. Each well definition in the data set therefore contains only one well ID record and as many stratigraphic and lithologic records necessary to define the well. Stratigraphic records contain data elements describing the name and boundaries of each stratigraphic interval in the well, and the lithologic records contain the bulk of the physical information in the well, that is data elements describing the physical interval boundaries, lithologies, textural descriptions, fossil records, minerals, and diagenetic, 
Stratigrophic Anolysis: Well Identification Worksneet

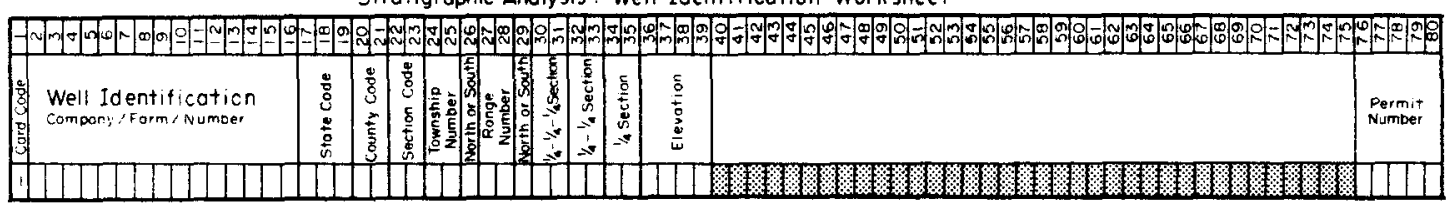

Strotigraphic Analysis: Stratigraphic Worksheet

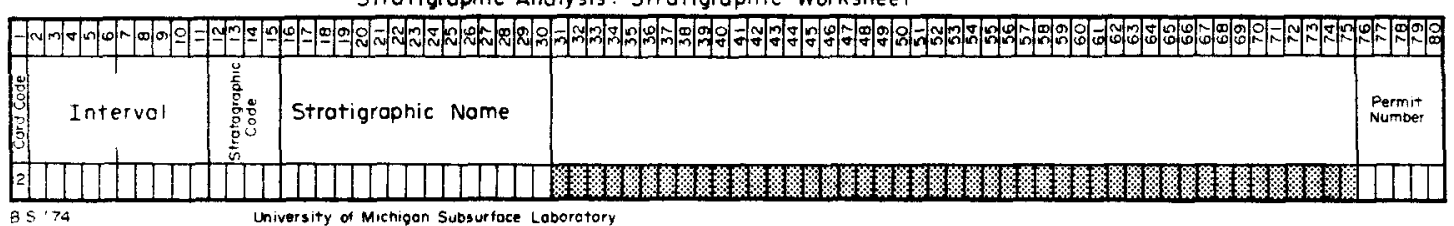

Figure 3. Well ID record worksheet and stratigraphic record worksheet.

Stratigrophic Analysis: Lithologic Worksheet
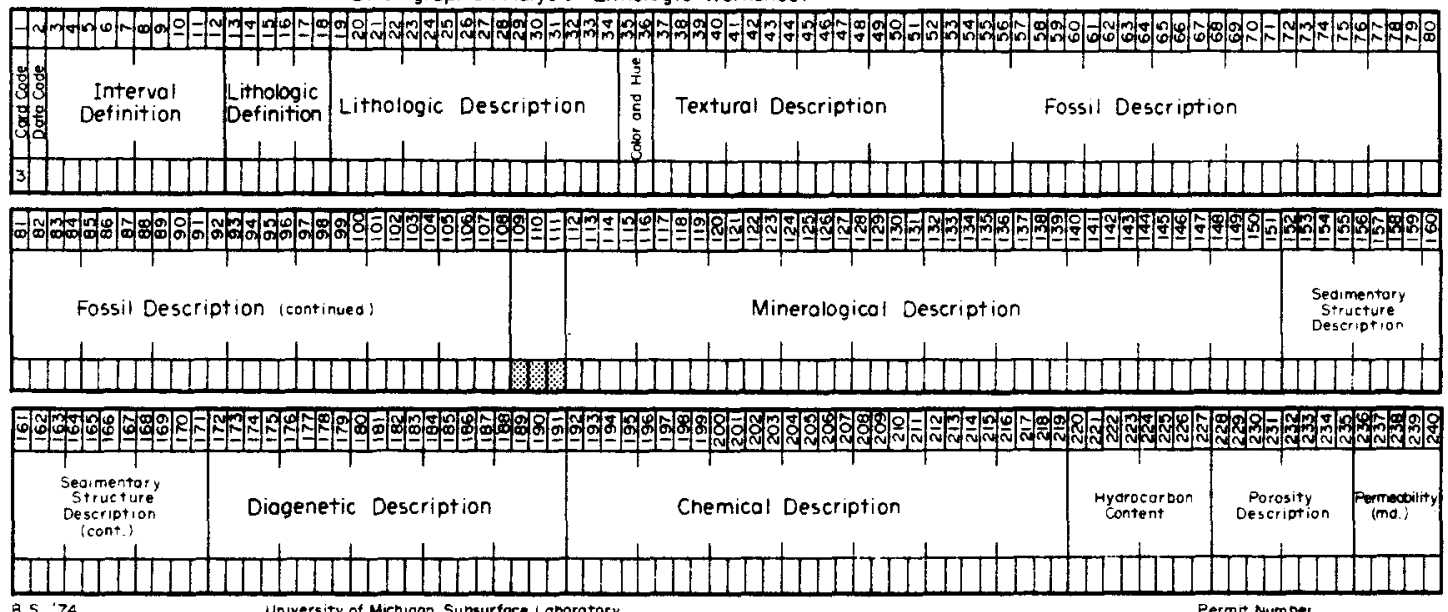

Figure 4. Lithologic record worksheet.

chemical, and other descriptive information such as permeability and porosity within any lithologic interval.

Stratigraphic and lithologic intervals are assigned arbitrarily to a well by the geologist. The applications of stratigraphic information being assigned to an interval as opposed to a horizon (stratigraphic 'top'), then creates a unique situation in which to accommodate discontinuities.

The major types of discontinuities encountered in subsurface analysis are produced by geologic gaps, such as disconformities, unconformities, faults, and nongeologic gaps such as missing data (Fig. 5). The data set of SAS does not require recognition of these features prior to analysis, but instead, an interval that contains no data (such as samples not collected) remains a valid interval in SAS. Missing stratigraphic information due to a discontinuity or fault is not assigned an interval, and the resulting juxtaposition of noncontiguous stratigraphic intervals identifies the discontinuity. Determining the nature of such a break is left to the geologist.

INTERNAL REPRESENTATION OF THE DATA SET

SAS loads the data set into central memory of the computer via the data-set loader. In central memory the records of the data set are kept in a large one-dimensional array. To index the array a list of tree-like struc-

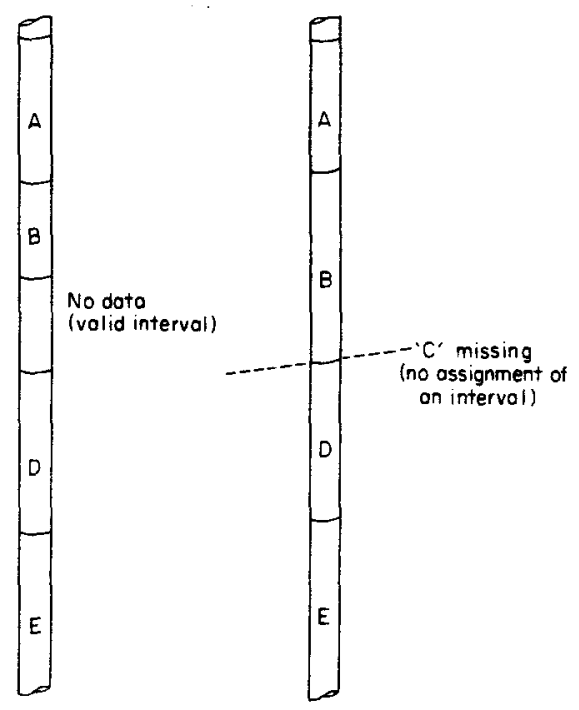

Figure 5. Discontinuities in SAS.

tures are generated. Each tree structure represents a single well, and each leaf or node of a tree is an index of a specific record of the well.

The process of loading and indexing the records in the data set can be shown by considering two hypothetical 


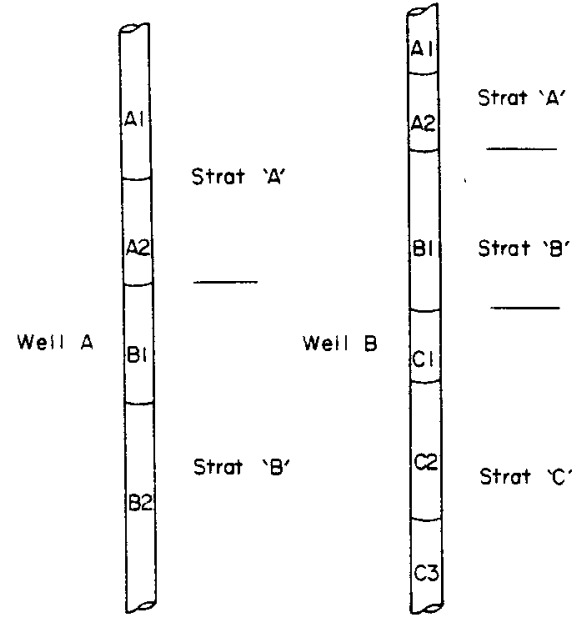

Figure 6. Hypothetical wells.

wells in the data set, well A and well B (Fig. 6). Well A contains two stratigraphic intervals, each of which contains two lithologic intervals. The second well, well B, contains three stratigraphic intervals separated into two, one, and three lithologic intervals respectively. In the data set, well $A$ is described with one well ID record, two stratigraphic records and three lithologic records. Likewise, well B needs one well ID record, three stratigraphic records, and six lithologic records. The internal indexing structure (Fig. 7) for these two wells then is composed of two three-level trees corresponding to the two wells. Note that the tree structures do not contain geologic information, but flags which index the large array with all the physical information. The purpose of storing the data in an array and indexing it with a tree structure is to allow sequential operations on the data as well as specific subsets of it.

\section{CONSTRUCTION OF THE DATA SET}

Accurate, uniform data are essential to the performance of any system. The data obtained from a well must be encoded into the three types of records comprising the data set. To establish uniformity, a data dictionary developed from Briggs and Briggs (1971) containing geographic, stratigraphic, lithologic, and other descriptive codes is used to construct records for the data set. However, the use of a dictionary has both advantages and disadvantages. The need to refer to a dictionary of codes when building the data set can be clumsy for occasional usage. In spite of this there are advantages which make use of this reference desirable. Standardized descriptions in geologic information systems are necessary if the system is to be used by many people with varied backgrounds. Subjective terms such as 'some', 'slightly', or 'occasionally' can be interpreted differently. For this reason only extremes or metric information are incorporated into the dictionary. Another advantage of encoding data is the decrease in physical size of the data set.

Specifically designed coding worksheets facilitates the encoding process (Figs. 3 and 4). Initial well data encoded on these forms can later be keypunched onto cards and then stored permanently on disk or magnetic tape. The information is stored in an internal dictionary in the data set loader, the codes on the cards representing the logical flags indexing the information in the dictionary.

\section{USING THE SYSTEM}

Using SAS involves initial execution of the program. then issuing a series of commands to the system to operate upon the data as desired. The command language is divided into two modes of operation: the SAS mode, and the EXAMINE mode. When the user is in SAS mode, he is able to issue commands which apply to all the wells in the data set, while in EXAMINE mode, commands apply only to a specific well. The purpose of a double-moded command language is to simplify the issuing of commands and to organize the commands into logical groups.

The user is initially in the SAS mode. To enter the

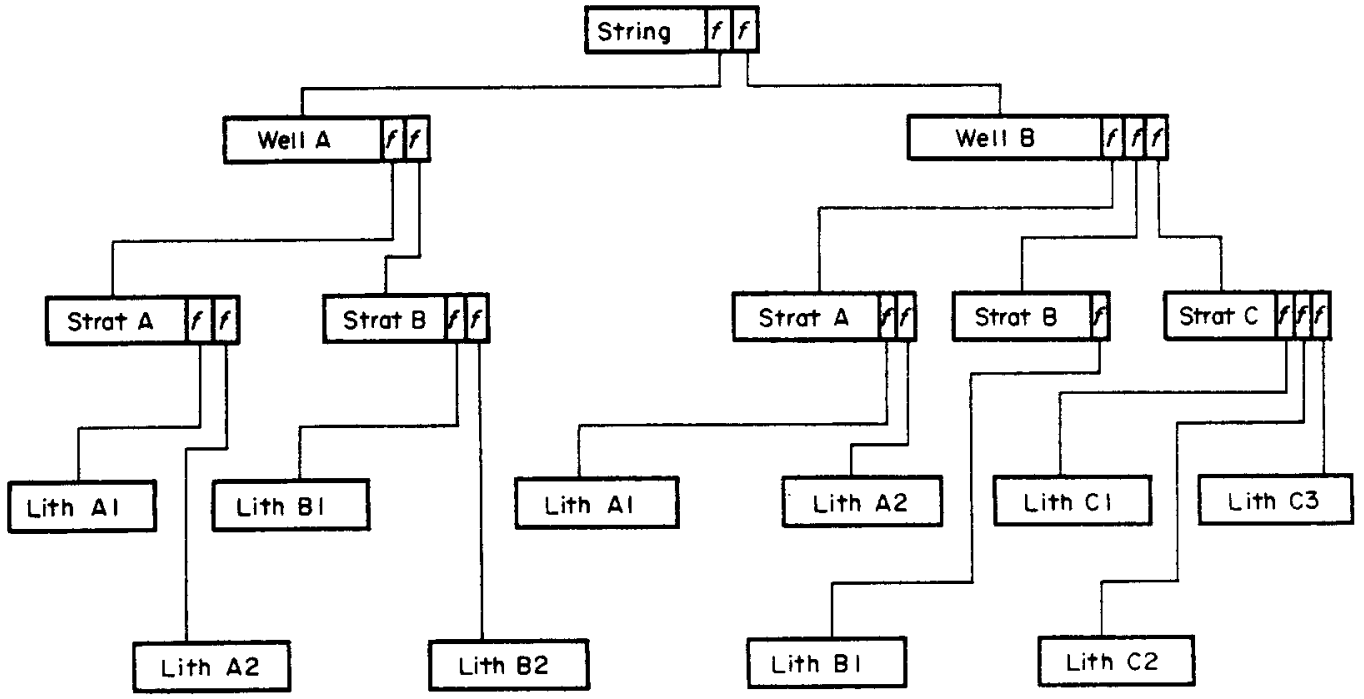

Figure 7. Internal representation of indexing structure in SAS. 
EXAMINE mode, an 'EXAMINE' command is issued to inform the system that subsequent commands will apply only to the well which is addressed. The 'SAS' command is given to reenter SAS command mode. The user is able to distinguish which mode he is currently in by the prefix character generated by the command processor for prompting purposes. A "+" indicates SAS mode, whereas a ":" signals EXAMINE mode (see Appendix I).

\section{CONCLUSIONS}

SAS is a new and young system. Its output functions and data manipulations are limited in number. What is important is that a framework has been developed and new data processors now can be added easily to the system. These processors could preform the functions of mapping, dynamic well creation, and statistical operations. Applications could extend beyond subsurface information to include other types of geologic information such as surficial geology.

SAS provides the geologist with a useful tool to enable him to simplify the processing and understanding of large amounts of information.

Acknowledgments-This work was begun initially as an in vestigation under Dr. L. I. Briggs at The University of Michigan. His expertise and comments have added greatly to the quality of the system. Funds for the system were provided by the Northern Michigan Project for 1974 administered by Dr. Briggs. The computing was done at The University of Michigan Computing Center.

\section{REFERENCES}

Briggs, L. I., and Briggs, D. Z., 1971, Thesaurus for geologic document analysis and information system (DIAS): Geoscience Documentation, v. 3, no. 3-4, p. 76-88.

Mosher, F., 1963, A computer oriented system in stratigraphic analysis: Inst. Sci. Tech. 66221-1-T. Univ. Michigan, 32 p.

University of Michigan Computing Center, 1971, The Michigan Terminal System, vol. 1: MTS and the Computing Center. Univ. Michigan, Ann Arbor, Michigan, p. 47-64.

University of Michigan Computing Center, 1972, ALGOL W in MTS: Computing Center Memo 199, Univ. Michigan, p. 13-14.

University of Michigan Computing Center, 1974, The Michigan Terminal System, vol. 5: System Services, Univ. Michigan, p. 191-202. 


\section{APPENDEX I}

The sample run presented here was preformed in 1974 when the system was being tested. The well displayed ('Test Well') is a hypothetical well. The coordinates and geology are imaginary.

The well contains 6 stratigraphic units, labelled A-F, and is located in Maracaibo county, Hawaii. There are 4 runs of the program displaying all or parts of the well. In the middle of the output is an example search and example error response.
The first display is of stratigraphic unit ' $C$ '. All well displays contain unit labels, symbolic display, footages, a brief lithic description, and relative percentages of the lithic elements.

The second display is of the entire well, this time at a scale of 1 in. $=200 \mathrm{ft}$. After the display there are a series of MTS commands ("\#" prefix) followed by a data search of wells in the system at the time. After this the same well is displayed at various scales.

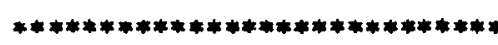

COORDIHATES: MHE 32-21N 6 H

STATE： HAHAII

COUNTY: $\triangle A E A C A I B O$

ELEVATION: 742 PEAMII NUABER: 11705

SCALE FACTOR: 1 INCH $=6$ IINES $=20$ FEET

\begin{tabular}{|c|c|c|c|c|}
\hline $\begin{array}{c}\text { SPAA } \\
\text { ONIGE }\end{array}$ & $\begin{array}{l}\text { CROS S- } \\
\text { SECIION }\end{array}$ & DEPTH & LIIHOLOGY & \\
\hline SESAT_C & 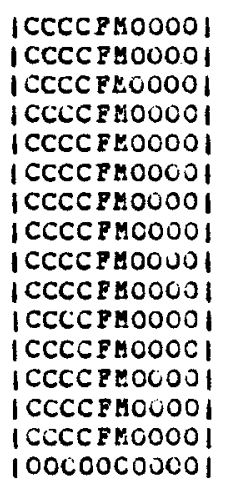 & -400 & $\begin{array}{l}\text { CALCAREOUS DOLOMITE } \\
\text { FOSSILIFEROUS LICRITZ } \\
\text { MICRIIE E DISLICAIIE } \\
\text { CTEER }\end{array}$ & $\begin{array}{l}42.75000 \\
13.75000 \\
13.75000 \\
29.75000\end{array}$ \\
\hline
\end{tabular}

END OF CEOSS-SECTION.

\begin{tabular}{|c|c|c|c|c|}
\hline $\begin{array}{c}\text { JIATIGEAFHIC } \\
\text { UHIZ }\end{array}$ & $\begin{array}{l}\text { UEOSS- } \\
\text { SECIION }\end{array}$ & БЕPTH & LIIHOLOSY & \\
\hline$S+d x I_{-}$ & 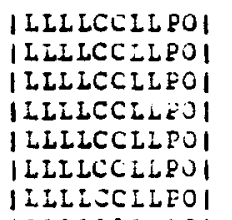 & 100 & 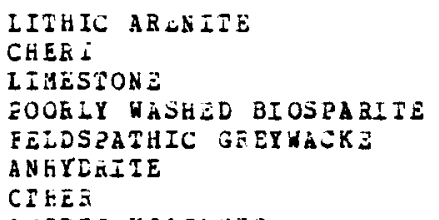 & $\begin{array}{l}40.61249 \\
13.94948 \\
10.36249 \\
9.122498 \\
2.042500 \\
1.282499 \\
9.607559\end{array}$ \\
\hline$s i d x^{2}=B$ & 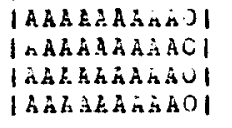 & $\angle \mathrm{LiO}$ & $\begin{array}{l}\text { ACIDEC VOLCHAZC } \\
\text { CTEER }\end{array}$ & $\begin{array}{l}90.25000 \\
9.750000\end{array}$ \\
\hline$j=\alpha A I_{-} C$ & 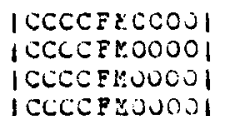 & 350 & 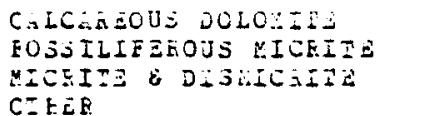 & $\begin{array}{l}42.75000 \\
13.75060 \\
13.75000 \\
29.75000\end{array}$ \\
\hline 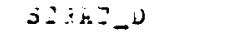 & 1 cececcosen & $+i v$ & COAL & $90.2500 \mathrm{uJ}$ \\
\hline
\end{tabular}




\begin{tabular}{|c|c|c|c|c|}
\hline & 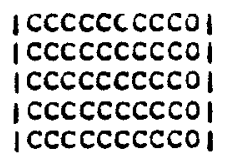 & & CI BEB & 9.750000 \\
\hline STRAI_E & 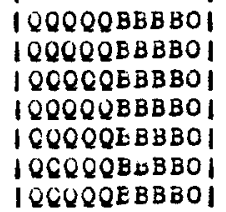 & -600 & $\begin{array}{l}\text { CUARTZ ARENITE } \\
\text { BIOLITHITE } \\
\text { CT UEB }\end{array}$ & $\begin{array}{l}52.25000 \\
42.75000 \\
5.000000\end{array}$ \\
\hline $\operatorname{STRAT}=F$ & 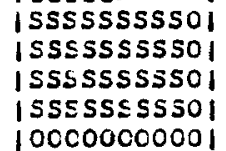 & $\begin{array}{l}-850 \\
-\quad 1000\end{array}$ & $\begin{array}{l}\text { SALI } \\
\text { CTHEE }\end{array}$ & $\begin{array}{l}90.25000 \\
9.750000\end{array}$ \\
\hline
\end{tabular}

: SAS

$+\operatorname{tin}$

- SSOU paEvious

* \$C * JUURCE*aSP *PEINT*

D FRINT* ASSIGNED FECEIPI NUABEE 644625

*PRINT* j446.25 DELEASED, 6 PAGES

- SuU sas.go

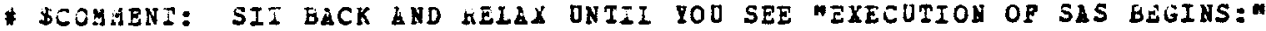

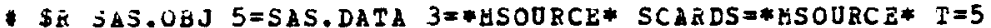

- exzCUizon begins

EXICUTION OF SAS BEGINS:

+ LOAD

NUKAER JF INPUI EECCEDS: 85 WUMER OP WEIIS DETECTED: 6

$+\operatorname{Haths}$

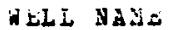

PEBIIT NUEBẼ EECORD

\begin{tabular}{|c|c|}
\hline 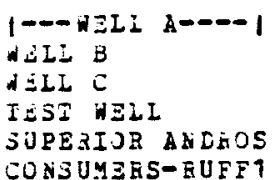 & $\begin{array}{l}12345 \\
54321 \\
11111 \\
11705 \\
00011 \\
24179\end{array}$ \\
\hline
\end{tabular}

ENE OF HELLS.

+ EXASINE IESI, WELL

*** AELL: TIESI.HELL DOES NOI EXIST.

+ EXFLAIN

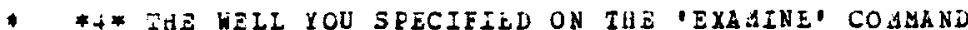

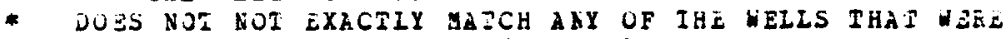

- in youz lata. jemember jhat a heli nahé

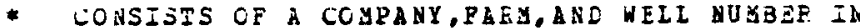

AEBREVIATED FORH. IF YCU CAY T REMEABER IHE EXACT

ABME OF A UELI, USE IT'S PERUIT NOMBER INSTEAD.

POE RXABPLE DSE:

IUSTEAD OF:

$$
\text { EXASINE } 21677
$$

$*$

+ EXAYINz TEST EEIL

: UNITS

\begin{tabular}{cccc} 
UNIT & TOP & BOTTCA & EECCRD \\
\hline STEAT_ & $1 C 0$ & 200 & 10 \\
STRAT_B & $2 C C$ & 350 & 19 \\
STRATE & 350 & 400 & 21 \\
STEAT_D & 400 & 600 & 23 \\
SIEAT_E & $6 C 0$ & 850 & 25 \\
STRAT_P & 850 & 1000 & 27
\end{tabular}

ZND OZ UNIES. 
- EISFLAYUTTL SCALE=150

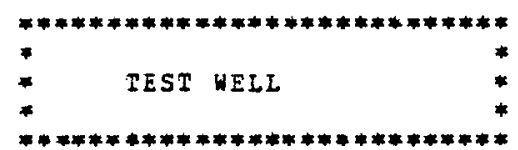

COOADINATES: NWE 32-21N OW

STAIE: HAWAII

COUNIY: YARACAIEC

ELEVAIICN: 742 PẼEIT NÜMBEA: 11705

SCALE FACFOE: 1 IACH $=0$ IINZS = 15J EZEI

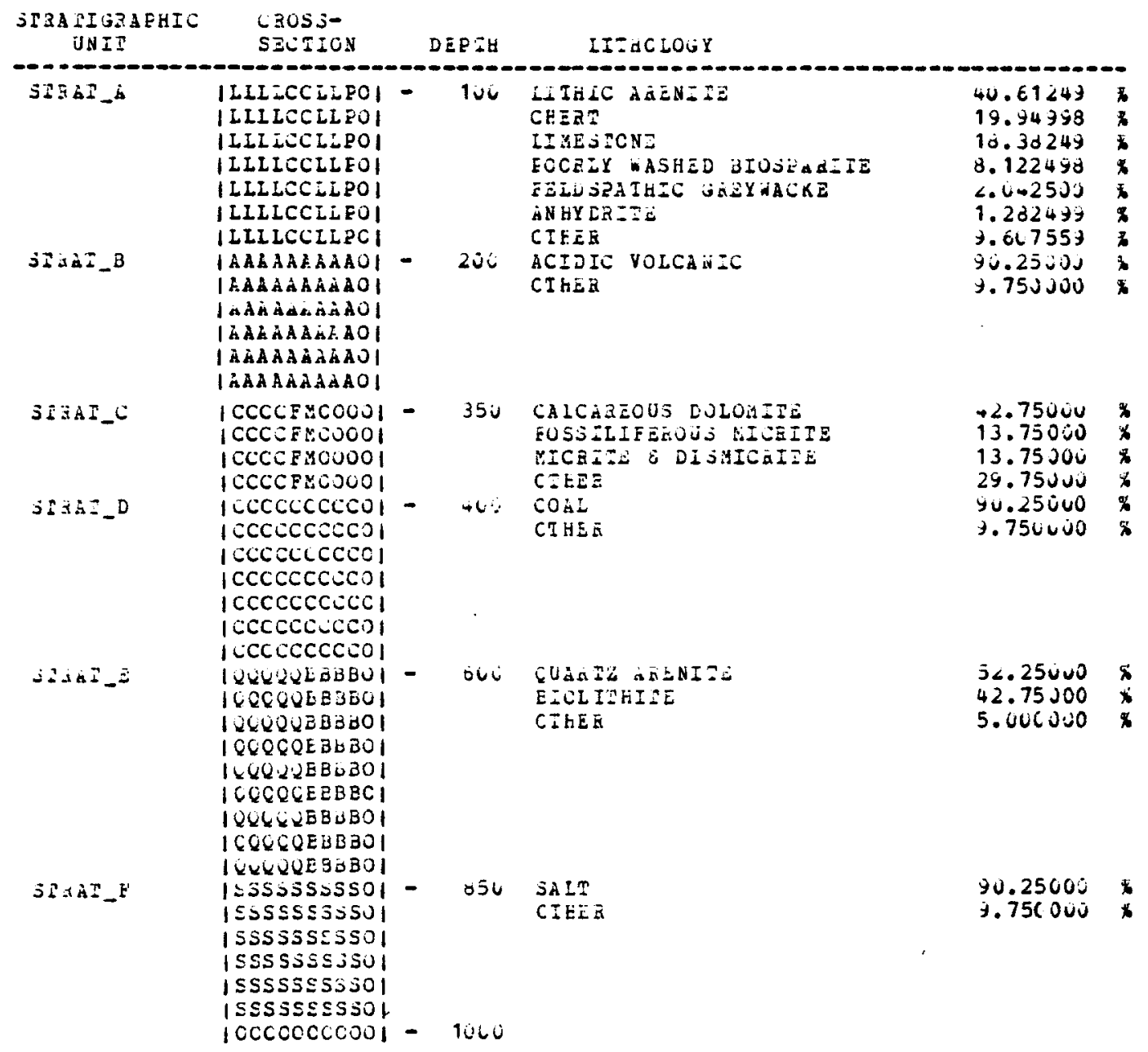

END OF CKOSS-SECIICH.

: jas

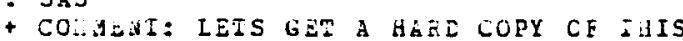

$+k . I j$

* DjJu pévious

* CONZKOL * PEINT* HOLD PEINT=EN

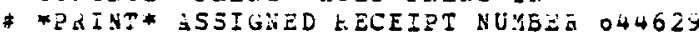

* DL *SOJAER*

\# GEj

+ LXASINE IEST WELI

- ijjilar jtát_c scale =50 


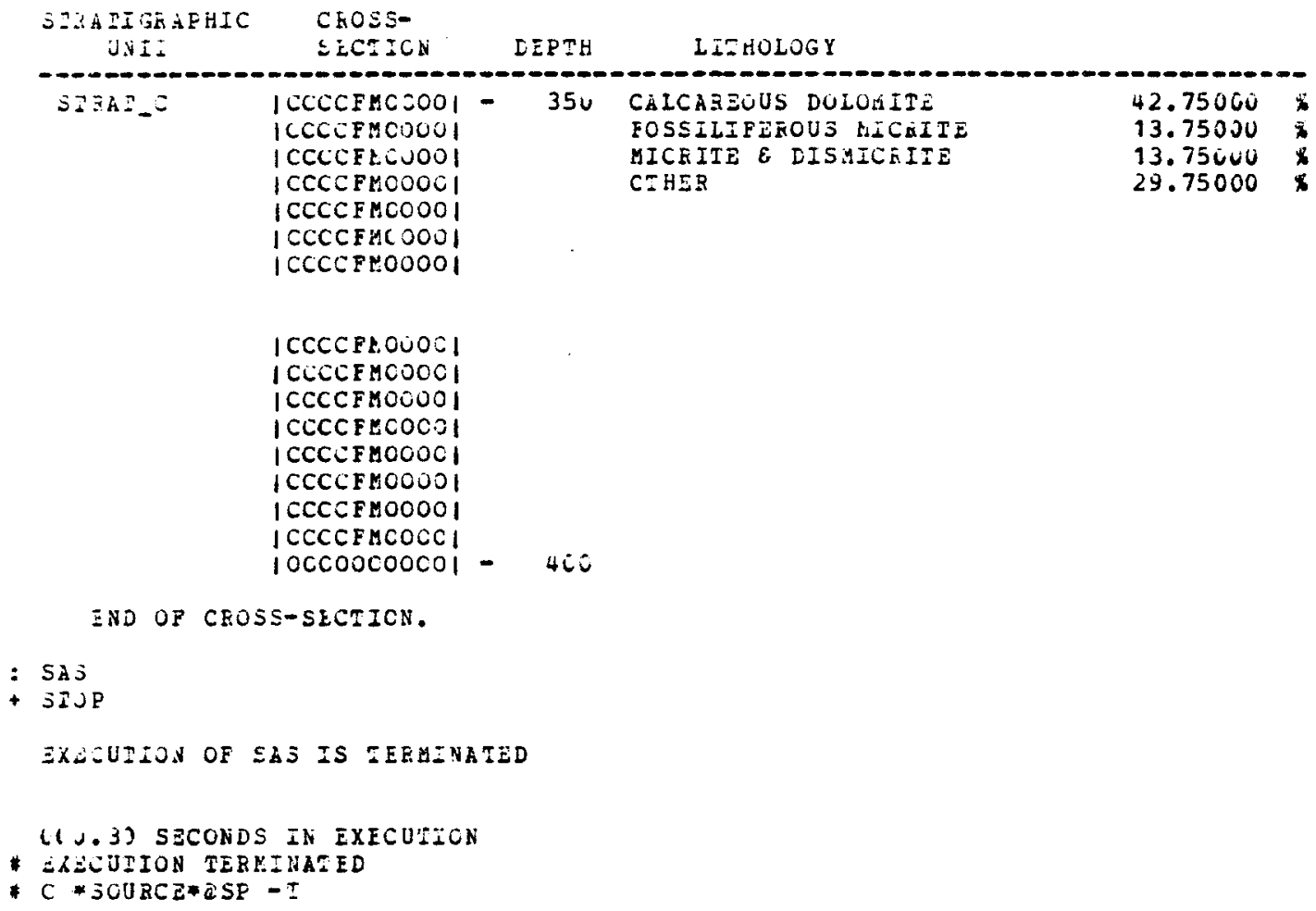

$\begin{array}{ll}\text { EOSSILIFEROUS ALCAITE } & 13.75000 \\ \text { MICEITE E RISAICEIIE } & 13.75000\end{array}$

CIHER

$29.75000 \times$

|CCCCFLOUOC|

I CCCCEMCOOOI

|CCCCF MOONOI

ICCCCE $\angle$ COCOI

1 CCCEFMOOOCI

ICCCCF 100001

I CCCEF 10000 |

I CCCCFMCOCC

100600000001 - 4is

END OF CROSS-SECTICN.

: SAS

+ SIJP

EXIEUTION OF SAS IS TEEHZNATED

(1 2.3$)$ SECONDS IN EXECUTHON

* ezecution terethated

* C * jOURCE*asf - I 


\section{APPENDXX II}

Appendix II contains the complete program listing. Only the lithologic portion of the internal dictionary was reproduced.

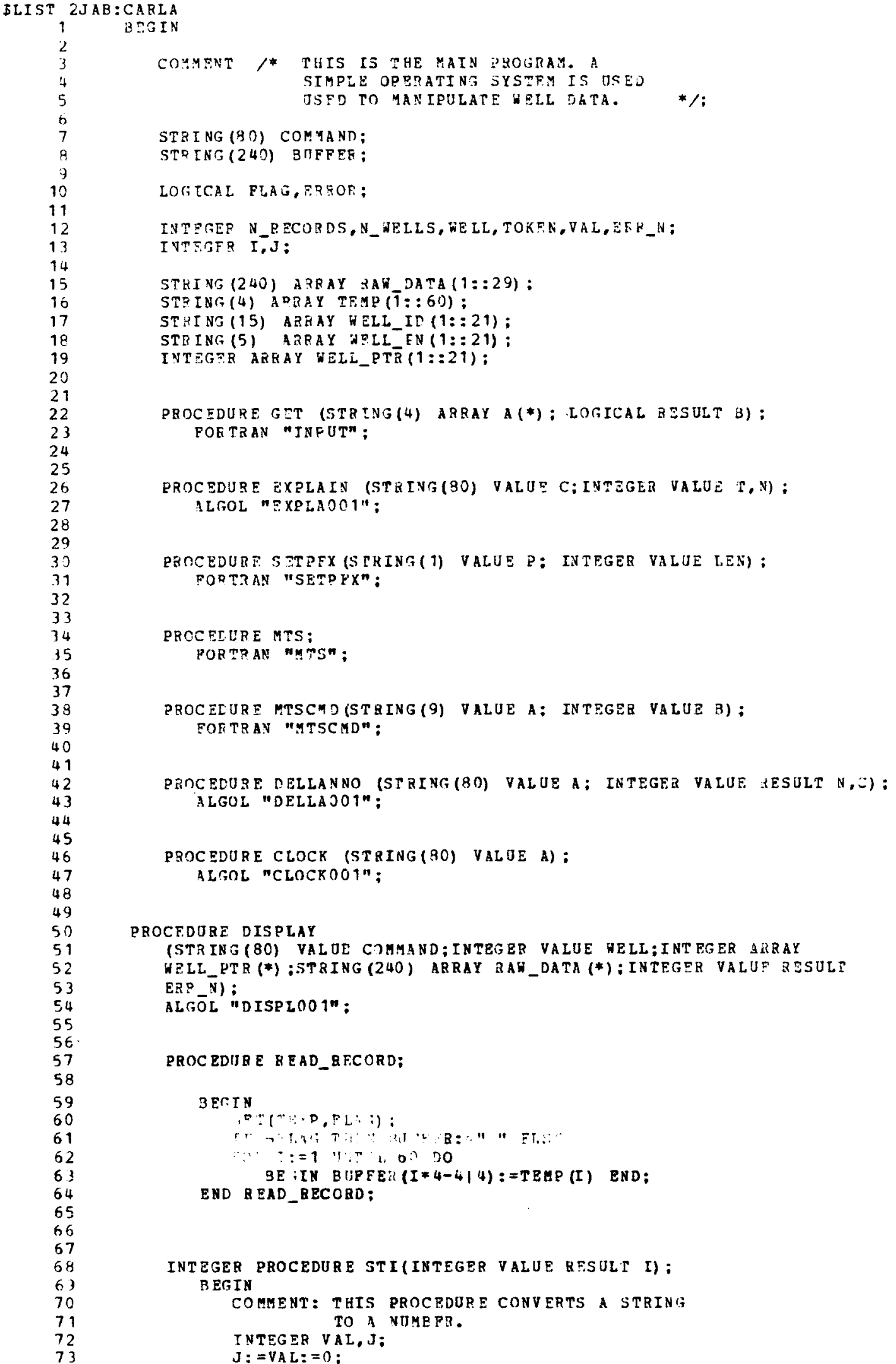




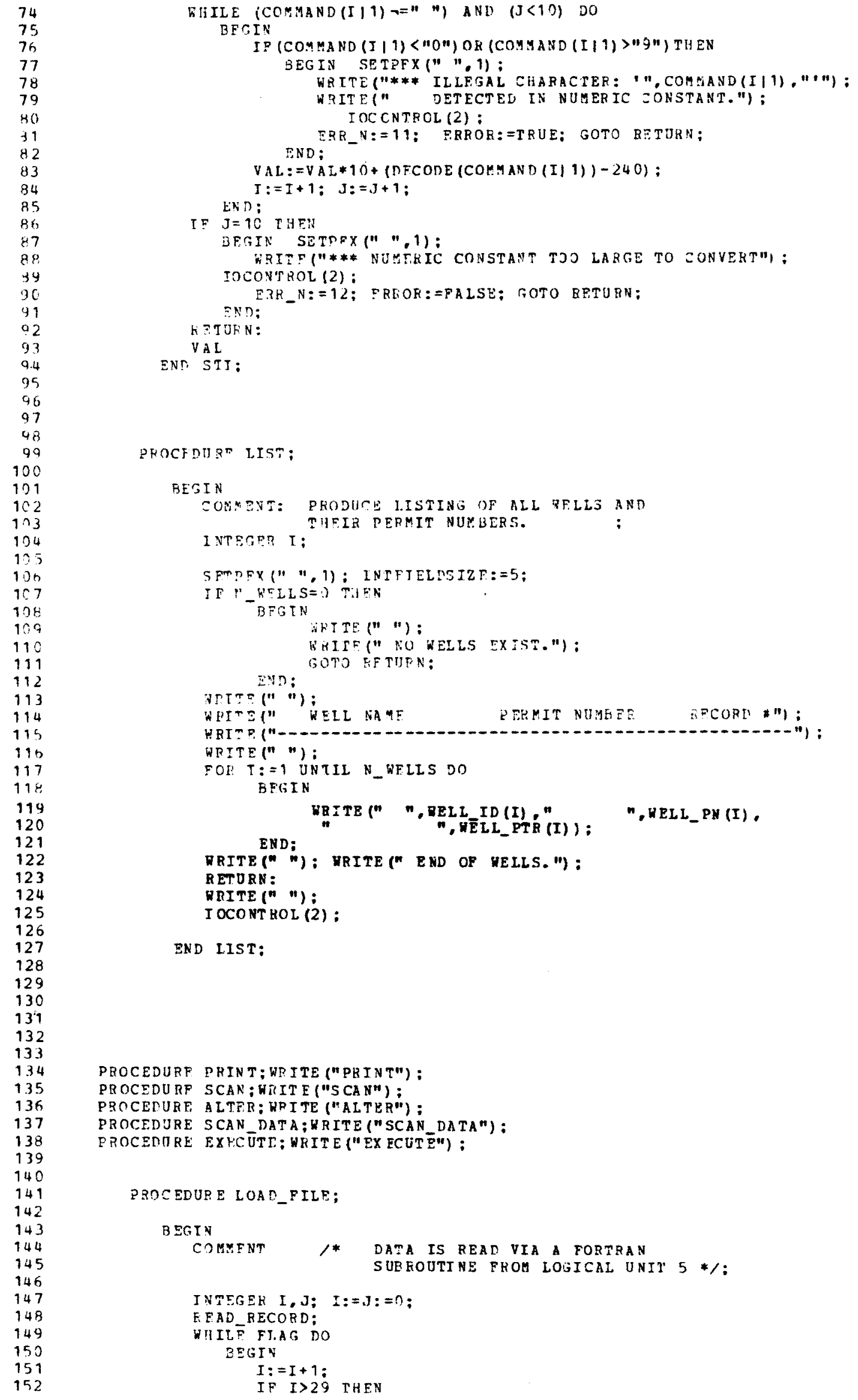




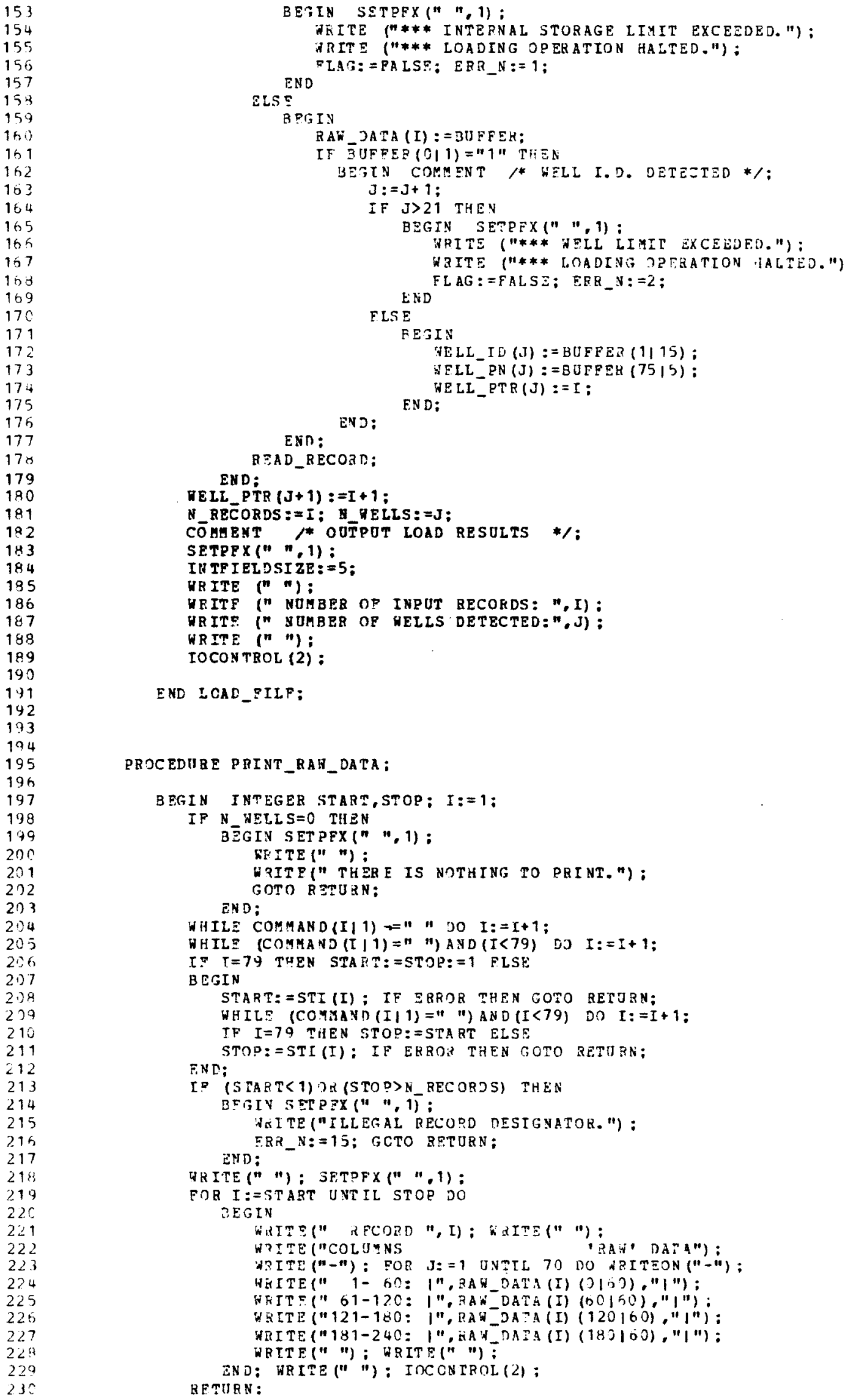


END PRINT_RAH_CATA;

PROCRRORF PRINT_STRAT_UNITS:

BEGIN IN TEGEP FIRST, LAST: PIRST:= HFIL_PTK(WF.LL)

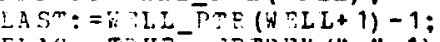

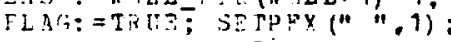

IN TEF I L TS I Z,E: : 5 ;

AITE (" "):

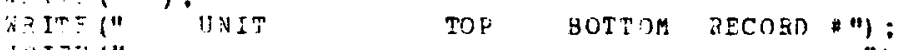

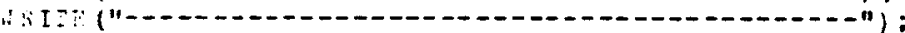

FOR I: =FTRST UNTIL ZAST DU

R:GIN TFRAN_DATA (I) $(011)=" 2 "$ TIIEN

TE U.A TIFN OKI TFF(" TUEK AES NG STRATIGRAPHIC UNITS. ") ELSE

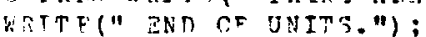

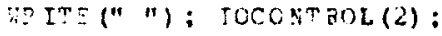

ENL) PATH_SHRAT_USTS:

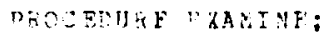


INTTGRR I, $\mathrm{X}$;

T $:=0 ;$ ERPOR:= FALSE;

HiIT.E COMMAND $(I, 1)=="$ "DO $I:=I+1$;

"HITE (COMMANO (I|1)=" ") AND $(i<79)$ กO $I:=I+1$;

TF $I=79 \quad M \quad I F N$

FIFGIN SFTRFX (" ", 1):

UHTTE("*** WELL NOT SPECIFIED."):

E $R$ OR: $=$ TRUE: IOCCNTFOL(2); ERR_N:=3; enn: GO TO RETIIN

If (COMYAND (I|1)<"O") OR (COMMASD (I|1)>"Y") IHEN BESIT

$\mathrm{J}:=1 ;$

MAILF (COMMANO(I/15) $=$ WEIL_ID(J)) AND ( $U<=\mathbb{N}$ NFLLS) DO $\mathrm{J}:=\mathrm{J}+1$;

IF J $>N$ MELLS THEN

GEGIA SETPEX (" ", 1)

HEITF ("*** WELL: " , COAHAND(I|15), "I DOES NOT EXIST."): IOCONTROL(2): $E N D$ FRROR: =TRUE; ERR N:=4; GOTO RETURN:

$\sin$

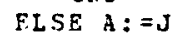

$S E$

BEGIN COM ENT: SEABCH WELL_PN'S;

$\mathrm{J}:=1$;

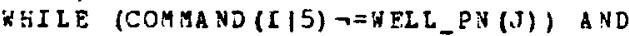

( $S<=N$ WELLS) $D O J:=J+1 ;$

IF (J>N WELLS) OB (COMAAND $(I+5 \mid 1)="$ ") TAEN URAIN SETPFX $(" ", 1)$ :

YRITR ("*** WELL: ' ", COM HAND(TI5).

"' DOES NDT EXIST."); IOCONTROL(2): END

ERROR: =TRUE; ERR N:=5; GOTO RETURN;

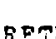

F.t.S: $A:=J$

EETUR :

END GFT_WELL:

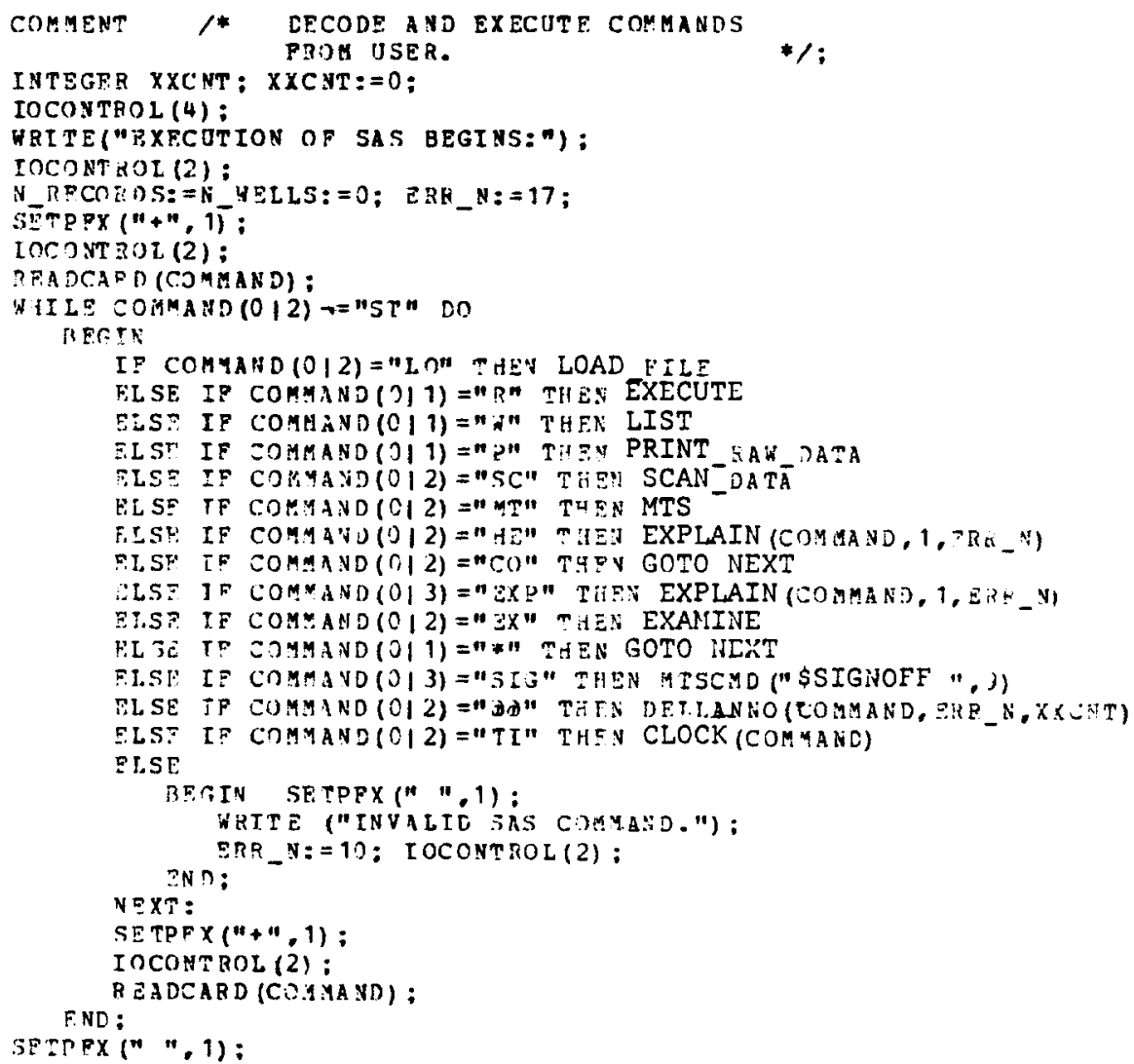


ERP TAB (25): = TINSTED OF:

ERR-TAB $(26):="$

EXAMIVE WRONGHFLLNAME

ERR TAB (27): : "*5* THE WRLI PERMTT NUMBER DOES NOT MATCA ANY OR ERZ_TAR (28): ="THE PERMIT NOMBERS THAT ARE IN YOUR DATA. ETPHFR FRR_TAB (29):="CHECK YOUR DATA, OR TRY ANOTHER PERMIT NUMBER. FRR TAB $(30):=1 * 6 *$ THE MODTPIER YOU USED, NO MATTER HOH CORBACR ERH TAB (31) $==$ "IT LOOKS. IS STILL ILLEGAL. LEGAL MODIEIFYS ARE ":

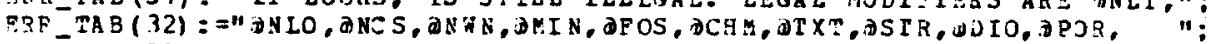

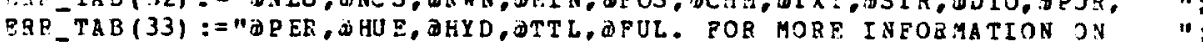
ERA-TAB (34):="MODI PIERS, GIVE THE FJLLOWING COMMAND: "; ERR-TAB $(35):=n$ BXPLATN NODIFIERS ERE-TAB (36): : **7* THE NAME OF THE STRATIGHARHC UNIT YOU SPECIRIES " ERE TAB (37): ="ON THE DISPLAY COMMAND WAS TOO LONG. NAMES OF" ERT_TAB (38):="STRATIGRAPHIC UNITS CAN ONLY BE UP TO 12 CHARACP TAS "; SRE-TAB (39): : = "LONG.

FRF TRB (40): $=" * 8 *$ THE STRATIGRAPHIC UNIT YOU SPECIFIRO ON THE ERK_TAB (41):="NISPLAY COMGAND DOES NOT MATCH ANY OF PHE UNITS IN" SRE - TAB (4?):="THE WELL YOU ARE EXAMININS. YOU PRJAABLY TYPED " ERE TAE (43):="TN THE YRONG CHARACTEF SOMENHERE.

FR?_TAB (44): : = *9* THE COMMAND YOU ISSUED DOES NOT EKIST IN LHE " ERK PAB (45):="'EXAMINP' MODE. ALL COMYANDS MUST BEAIN IN CULIJIN 1." ERY TAB (46):="*10* THE COMMANS YOH ISSUED IS NOT A SAS COAAAND. "? ERB $T A B(47):=$ "ALL COMMANDS MUST $F=;$ IN IN COLUMN 1 . ";

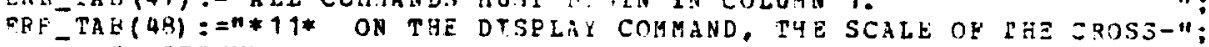
$\mathrm{J}:=\mathrm{PTP}(\mathrm{N}) ;$

NEITE (" n , TRR_TAB (J)):

$\mathrm{J}:=\mathrm{J}+1:$ WHILE FRP_THE(J) $(0,1) \neg=n *$ " DO BE, IN END;

$$
\begin{aligned}
& \text { NRTTE(" N,FRR_TAB(J)): } \\
& \mathrm{J}:=\mathrm{J}+1 ;
\end{aligned}
$$

FNI) TLLE

TF $\mathrm{N}<20$ THEN

B Bitid

STEIVI (53) AERAY ERB_TAB (48::92): INTEGPR AREAT PTR(11::20): $\operatorname{PTP}(11):=48 ; \quad$ PTR $(\overline{1} 2):=53 ; \operatorname{PTR}(13):=57: \operatorname{PIB}(14):=63 ; \operatorname{PTR}(15):=58 ;$ PTK $(16):=75 ; \operatorname{pTP}(17):=76 ; \operatorname{2TR}(18):=77 ; \operatorname{pTR}(19):=83 ;$ PTR $(20):=88 ;$ ERT-TAB $(48):=1 * 11 *$ ON THF DISPLAY COMHANU, THE SCALE OP TIE ZROSS-": ERF_TAB (49):="SPCTION CAN AE SET USIN. THE 'SCALE= PALARETPR. THE ": SRP TPA (50):="SCALO CAN ONIY BE SFT TJ A NUMRIC ZONSTANT. THAT I: ERF-TAB (51): ="MEANS A STRINi OF UP TO 9 DIGITS, NOT CONTAININO ANY ": PKR - $A B(52):=$ "BLANKS OB NON-NOHEITIC CHAGAETERS.

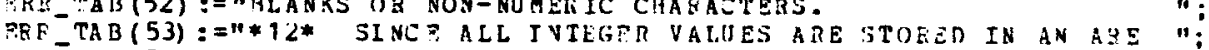
ERR_TAB (54):="OF LIMITED SIZE, TIEEF IS A LIMIT ON TUE SILZO? 725-TAB (55):="NUMERIC CONSTANTS TIAT CA: BE USRD. IN SAS THE IIMIT ":

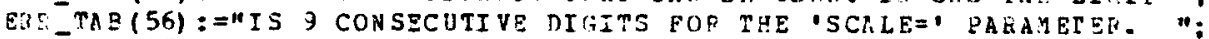
FRE TAB (57):="*13* THE VALUE SCALE IS SET TO, DETERAINES " ERR TAB $(58):=$ THE NOMBER OF FPET THAT HILL BE REPRESENTED "; ERA-TAB (59): ="BAT ONE INCH OF THE PRINTED CROSS-SECTION. RRR TAB (60):=WAS TAE VALUF OP SCALE $\Rightarrow$ ZERO, THE LENGTH ERR TAB $(61):=" O P$ THR CROSS-SECTION APPROACHES INPINITY ERR TAB (62):=n--SO ZERO IS AN ILLEGAL SCALE PACTOR. SRF TAB (63): =N*14* THEHE WAS A NON-NUMERIO CHARACTER IN THE FPR TAB (64):="INTERYAL COLUMNS OF TYE DATA REZORD. PROBABLY ERR TAB $(65):=" A$ REYPUNCP ERROR. AN INTEHVAL CONSISTS OF TWO EPR-TAB (66): ="PIVE DIGIT INTEGPRS SPECIFYING TIP TOP AND FRR TAB $(67):=$ "BOTTOM OF THE INTERVAL.

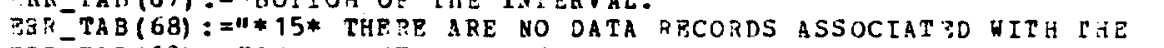
ERR_TAB (69):="RZCORD YIBBER YOU SPECIFIED ON THE 'PRINT, ERE- TA (70):="COMMAND. EITHER YOU HAVEATT ENTEBED ANY DATA THP TAE (71):="ZITH THP 'LOAD' COMMAND, OR YOU SPECIPIED A ERE_TAB (72):="NUMBER THAT הAS TOO HIGi OR ZERO. TAE 'LOAJ. TER TAB (73):="COMMAND NUMEERS EACH RECORD SEOUENTIALLY STARTERQ_TAR (74):="IYG WITH 1 . TRP TAB (75):=N*16* TOUR INTERVALS ABE IN TAE DRONG ORDRR. ";

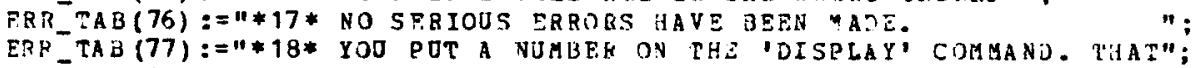
ERT-TA3 $(78):="$ NUMBER NRS TNTERPRETED AS A RECOBD DES ÍNATOR. APTER": ERE LAR (79): "A 'LOAD" COMMAND BACH RECORD IS ASSIGNED A NUMBER ": ER- TAD (80):="STARTING KITH 1. YOU SPFCIFIED A RECOAD TSAT IS NOT "; ERF TAB (81):=" TI THE HELL YOU A EE FXAMINING. (BLMEMBER FHAT IN" "; ERL_TAB (H2) :="FXAMINE MODE ONLY 1 WELL AT A TIME CAY IZ WOSKEJ OS ";

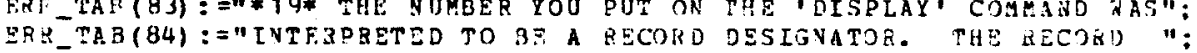

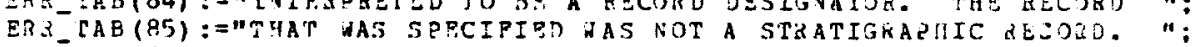

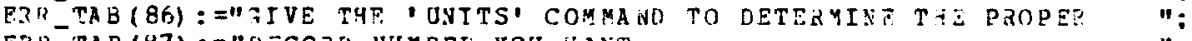

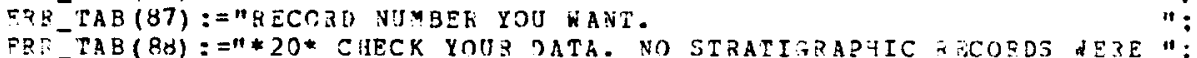




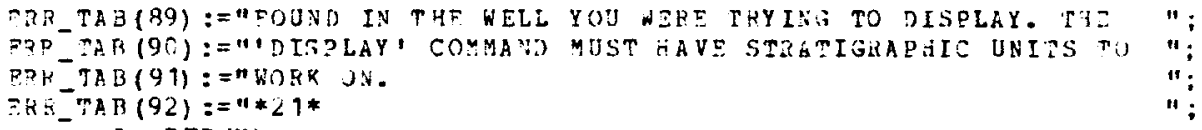

$\mathrm{J}:=\mathrm{PTP}(\mathrm{N}):$

KRITF(" "ERK_PAR (J)) :

$\mathrm{J}:=\mathrm{J}+1$;

WHILE PRR_TAB(J) $(011)=$ BIGIV WDITE(" ",ERP_TAB(J)): ENT: $\mathrm{J}:=\mathrm{J}+\mathrm{T}:$

END:

FND MESSAGF

STRIN(7) (7) ARBAY $\operatorname{COM}(1:: 23)$ :

INTEC $2 \pi$ I:

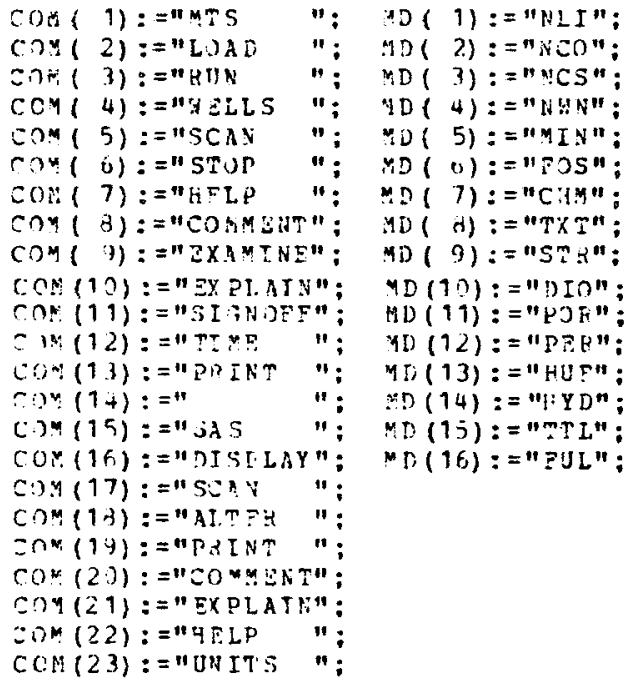




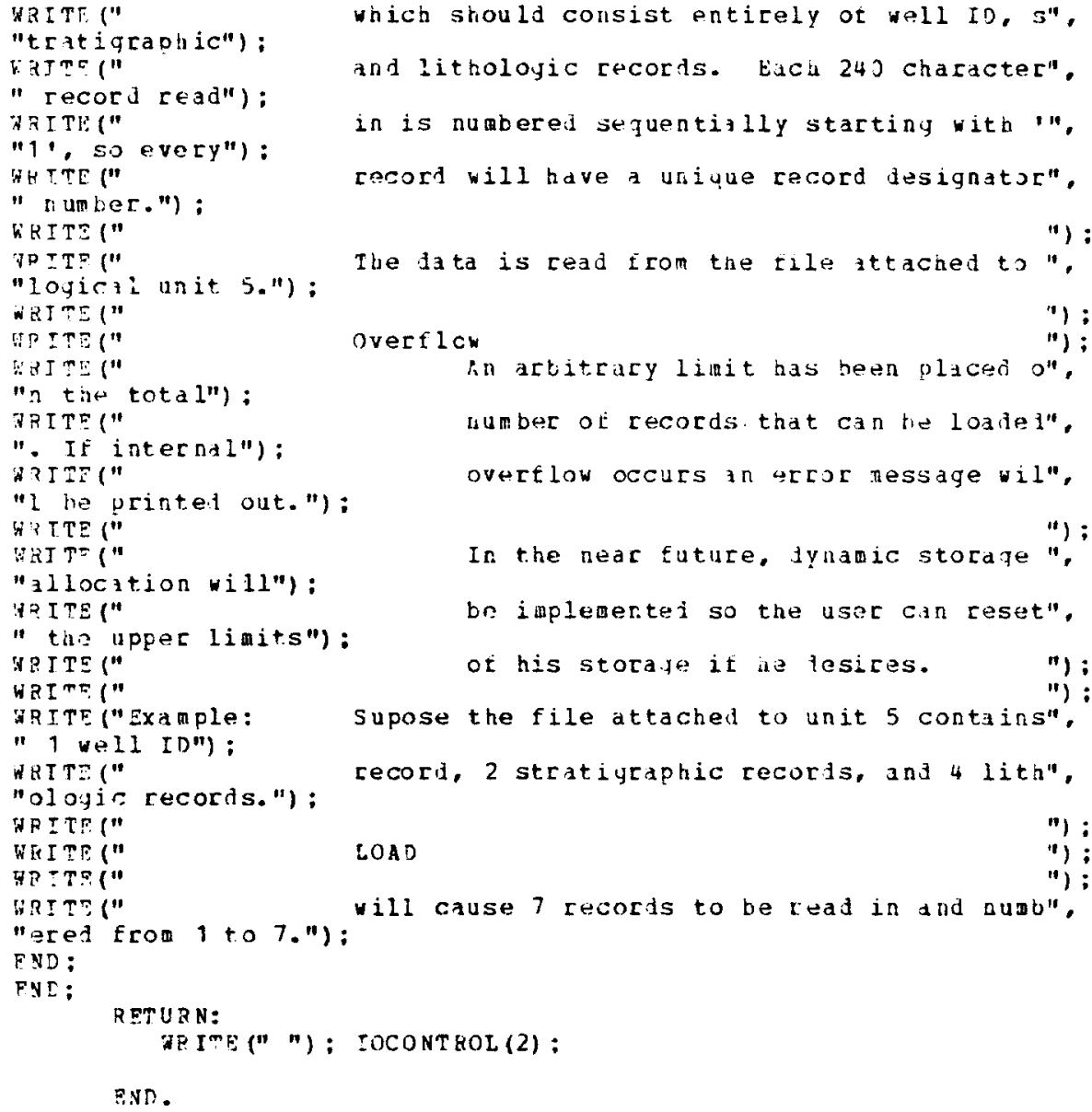




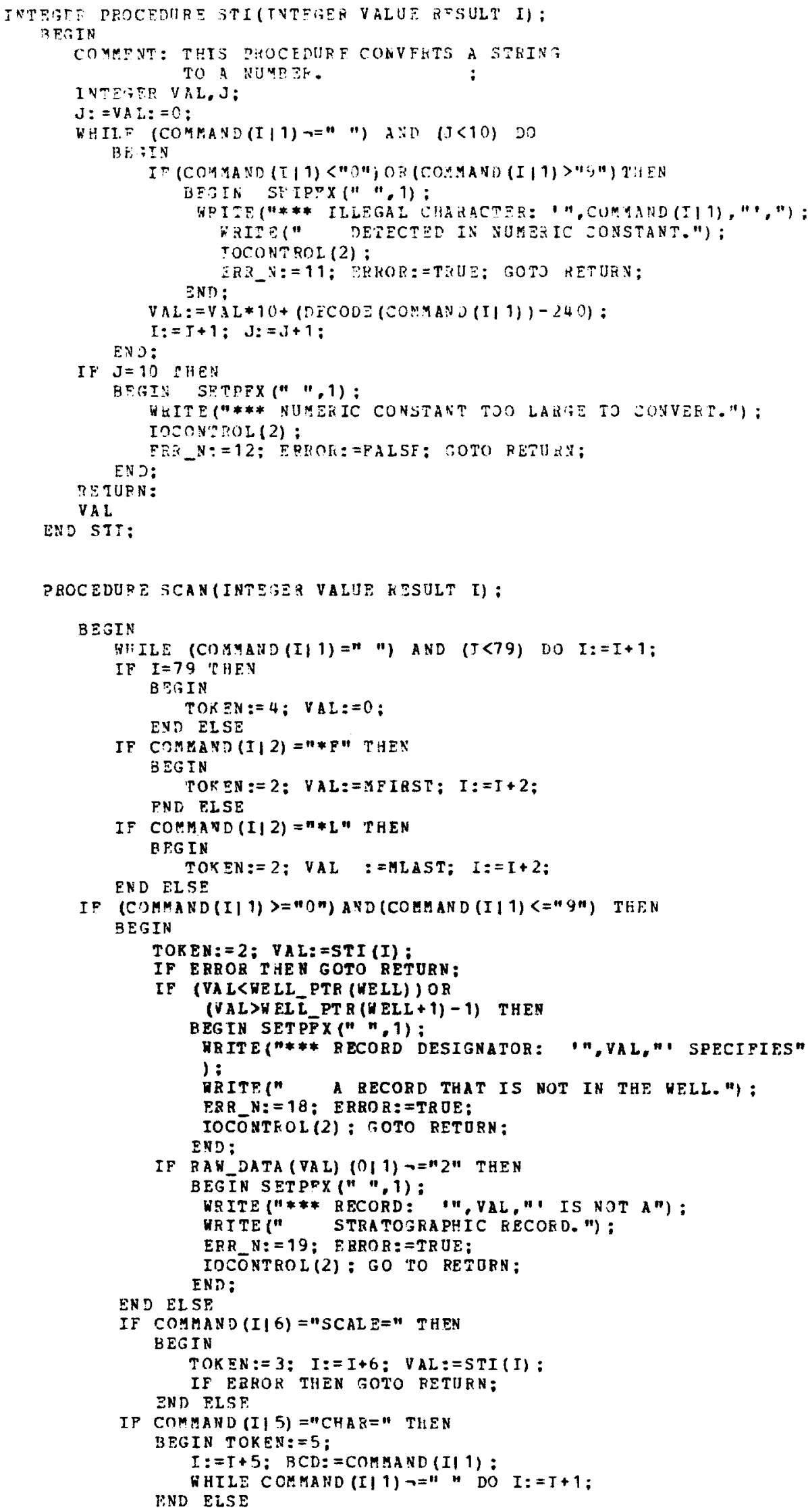




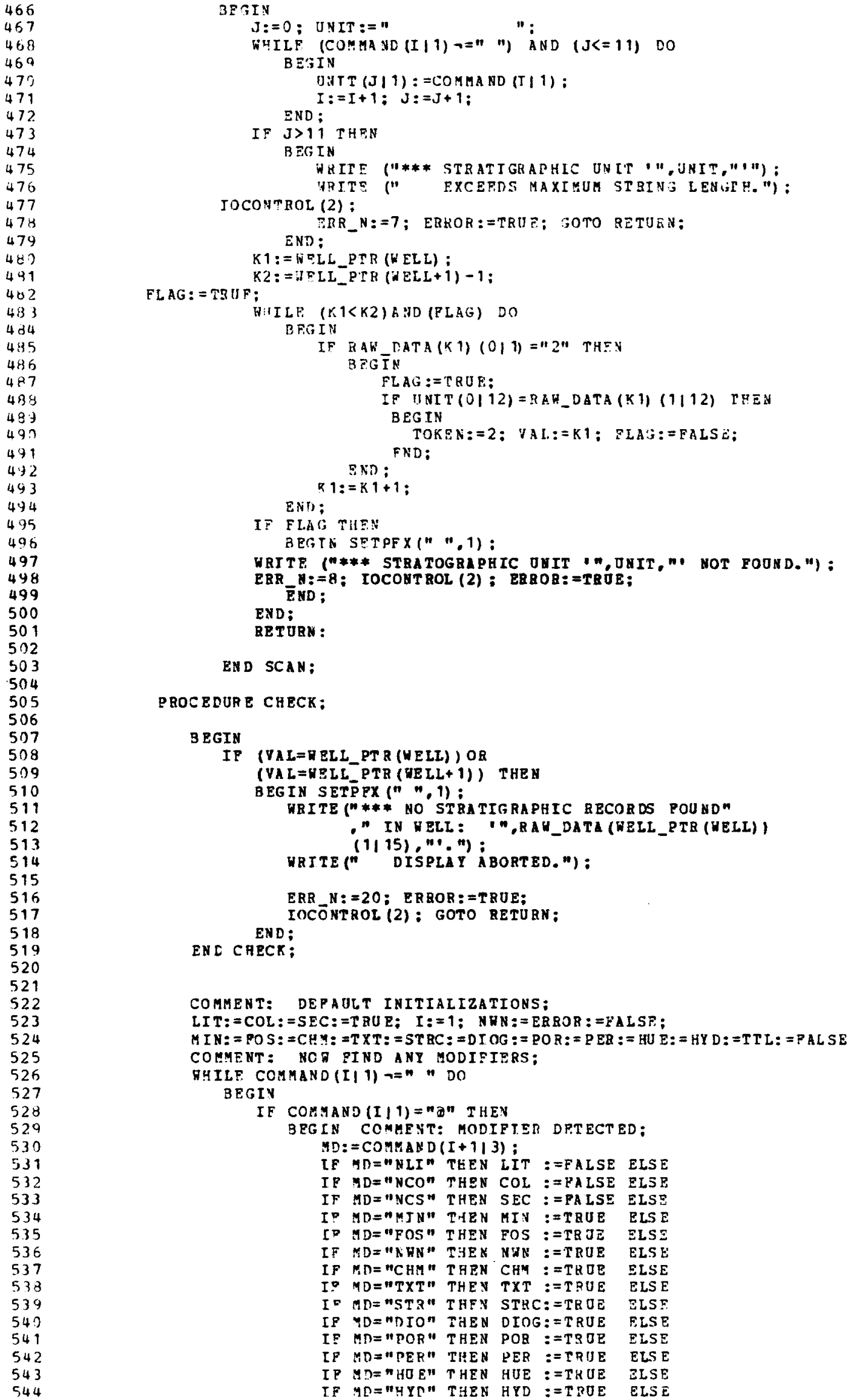




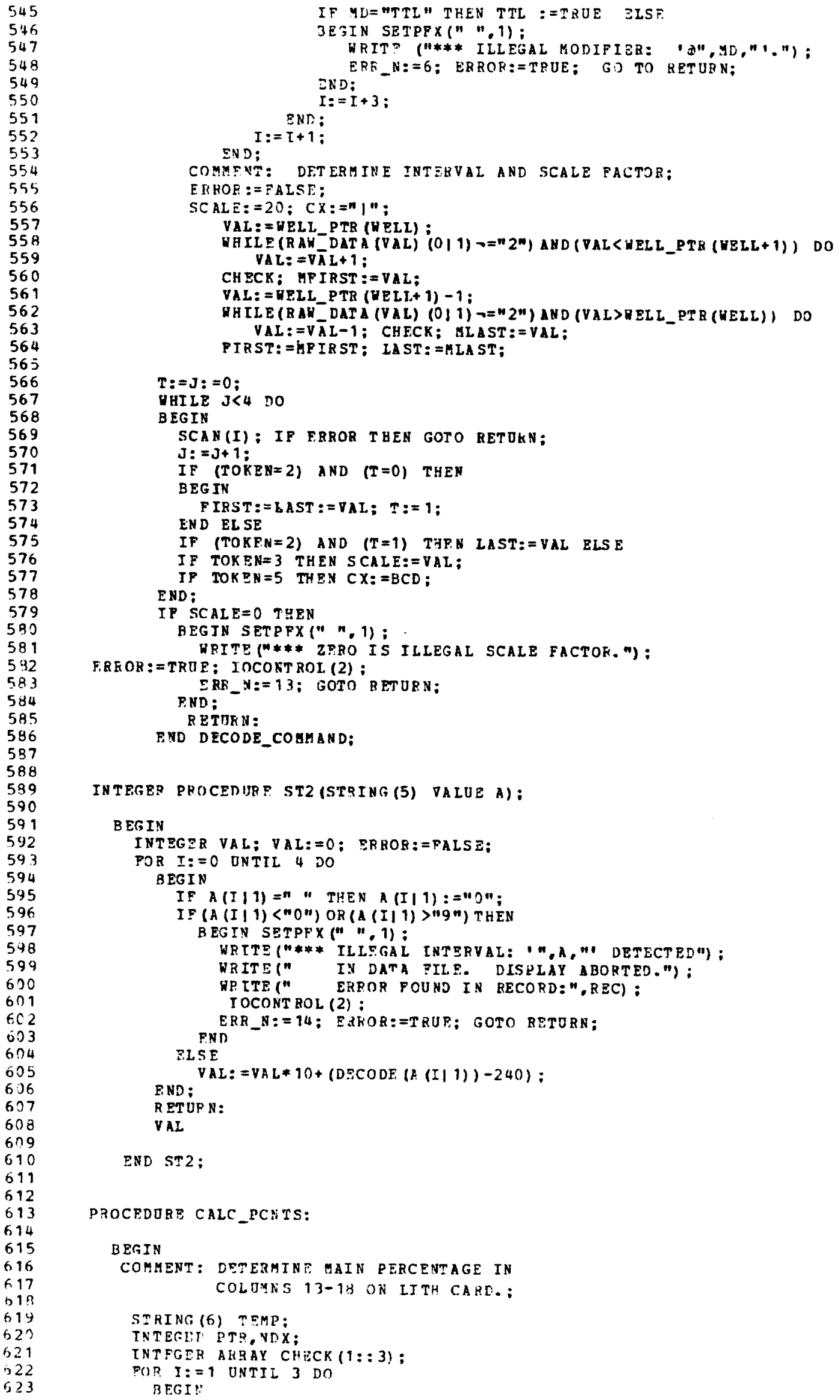




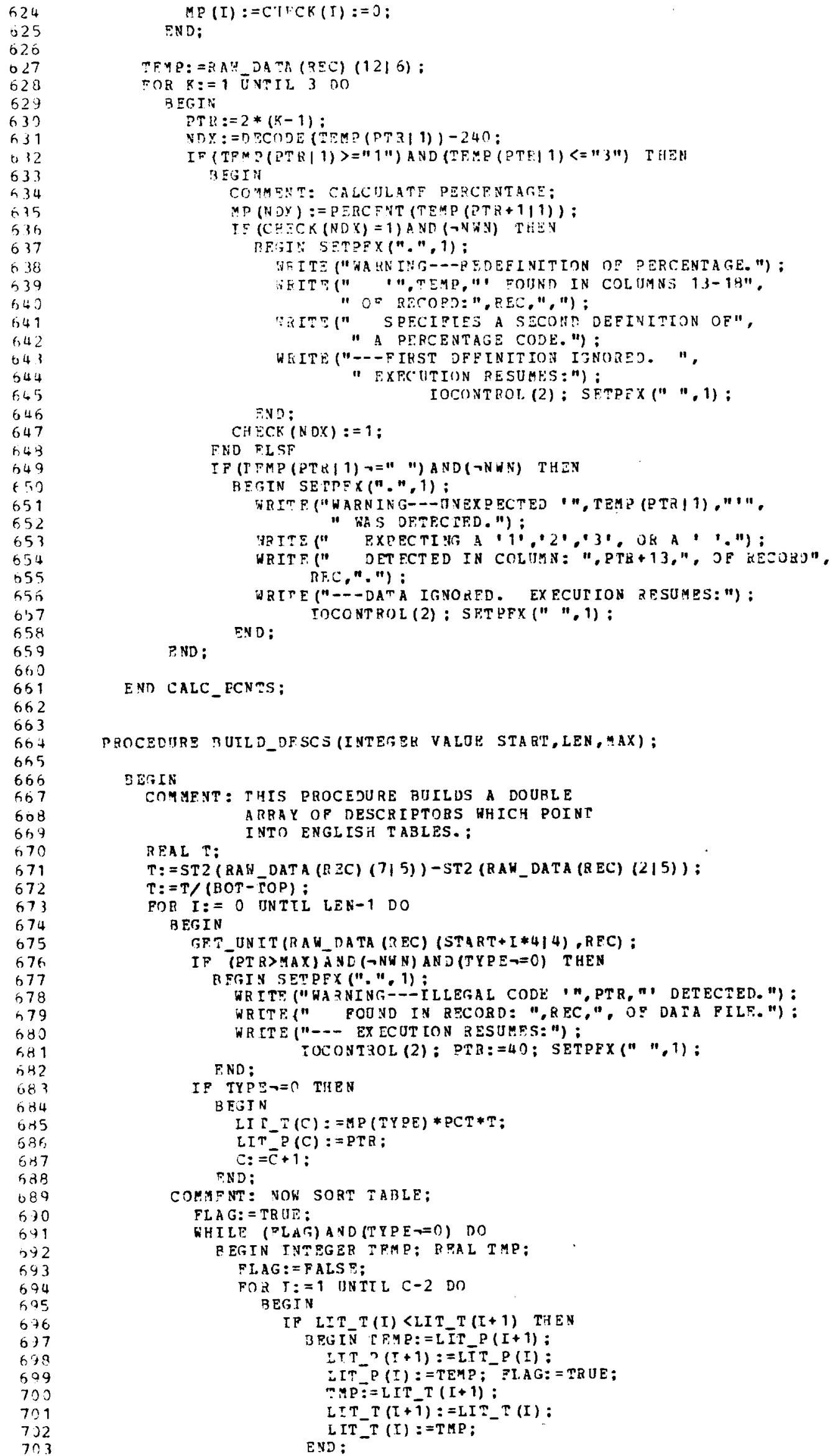


END :

IF LIT_P $(I)=I I T \_P(I+1)$ THEN

BEG IN

LIT_T (I) : =LIT_T (I) +LIT_T $(T+1)$ :

FOP $K E=I+1$ UNTIZ $C-1$ DO

BEGIN

LIT_T $(K):=L I T+T(K+1)$; RND;

LIT $P(K):=L I T P(K+1):$

END; $=\mathrm{C}-1 \cdot \mathrm{s}$

END:

END:

END BUILL_DESCS:

PROCFNURE COHPOSF_LINE:

BEG N

COMHFNT: CROSS SECTION LINE FIRST:

INT EGE: I, J,R:

P.AL A:

STHING(10) CHAR:

LINE: = " 0000000000n ;

$\mathrm{J}:=0 ; \mathrm{I}:=1$ :

WHILF $(I<C)$ ANก $(J<10)$ DO B EGIN

$A:=\operatorname{LIT} T(\mathrm{I})$

FOR K: $=0$ UNTIL 9 DO CHAR (K|1):=LIT_TAB(LIT_P(I)) (3|1):

IF (A>5) AND(A<15) THEN BEGIN LINE (J|1):=CEAR(0,1);J:=J+1 END

ELSE IP $(A>14)$ AND $(A<26)$ IHEN BEGIN IINE $(J \mid 2):=C H A R(0 \mid 2): 3:=J+2$ END

EL SE IP (A>25) AND (A<35) THEN BEGIN LINE $(J \mid 3):=$ CHAR $(0 \mid 3): J:=J+3$ END

FLSE IF $(A>34)$ ANT. $(A<46)$ THPN REGIN LINE $(J \mid 4):=C H A R(0,4): J:=J+4$ EN

ELSF IF (A>45) AND (A<55) THEN BEGIN LINE $(J \mid 5):=C H A R(0,5) ; J:=J+5$ END

FL SE TP $(A>54)$ AND $(A<66)$ THEN EEGIN LINE $(J \mid 6):=C H A K(0,6): J:=J+5$ END

FLSE I: $(A>65)$ AND (A<75) THEN BEGIN LINE $(J \mid 7):=C H A S(J \mid 7): J:=J+7$ ZND

FLSE TF $(A>74)$ AND $(A<86)$ THEN BFGTN LINE $(J \mid 8):=C H A R(0 \mid 7): J:=J+7 \quad 6 N$

ELSE IF (A>74) AND (A<A6) THEN BEGIN LINE (J|8):=CHAR $(0(3): J:=J+8$ END

FILSE IF (A>95) AND (A<95) THEN BFIGN LINE $(J \mid 9):=C H A R(0 \mid 4): J:=J+9$ END

FLSE. IP $(A>94)$ THEN BEGIN IINE $(J \mid 10):=C H A P(0 ; 10): J==J+10 ;$ END:

$I:=I+1:$

END

END CCAPOSF_LINE;

PROCEDURE GET_UNIT (STRING (4) VALUE UNIT; INTEGEE VALUE HEC):

BETIN

INTEGER PROCEDURE STI (I HTEFEF VALUE $P, L$ )

BEGIN

INTEGER $V: V:=0$;

FOR I: $=\mathrm{P}$ UNTIL $\mathrm{P}+\mathrm{L}-1$ DO

BEGIN IF UNIT (I,1)=" "THEN UNIT(II1):="O":

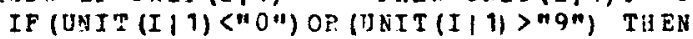

BEGIN SETPFX(".", 1):

WRITE ("WARNING---ILLEGAL DESCRIPTIVE UNIT.");

WRITE (" " "UNIT," WAS DETRCTED IN RECORD:", REC." OE CATA FILE."):

NRTTE ("--UNI' IGNORED. EXECUTION RESUMES: ") ; FBROR:=TRUF:

ENO GET_UNTT: 

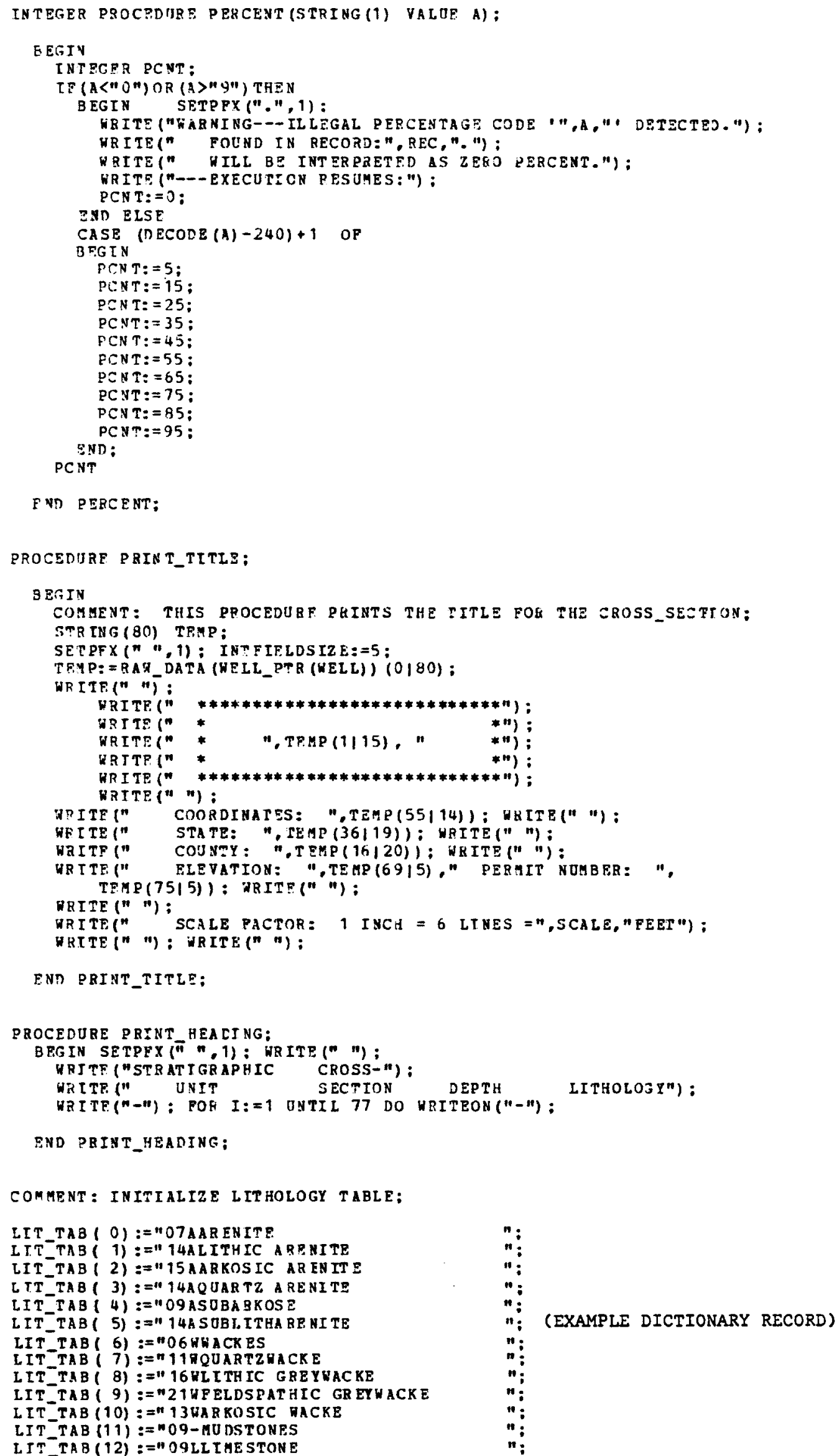


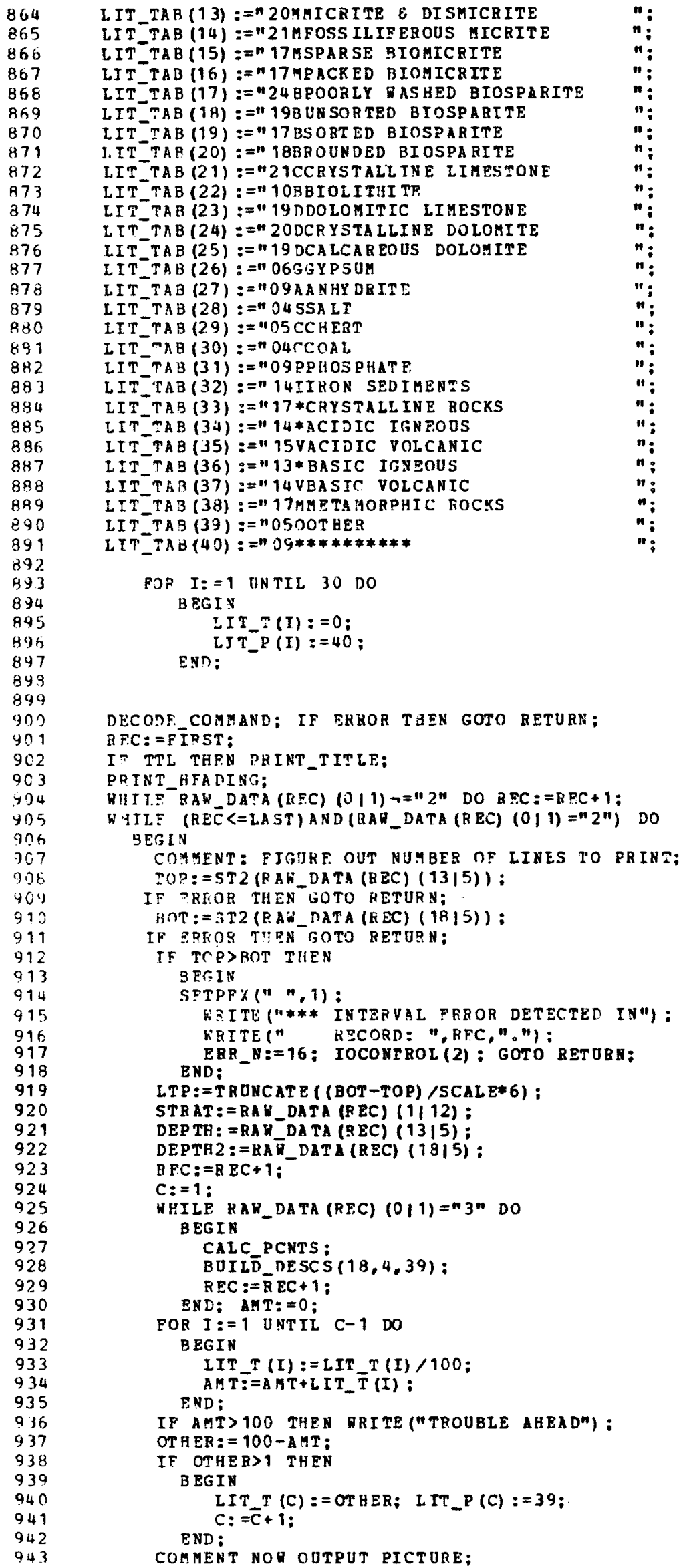




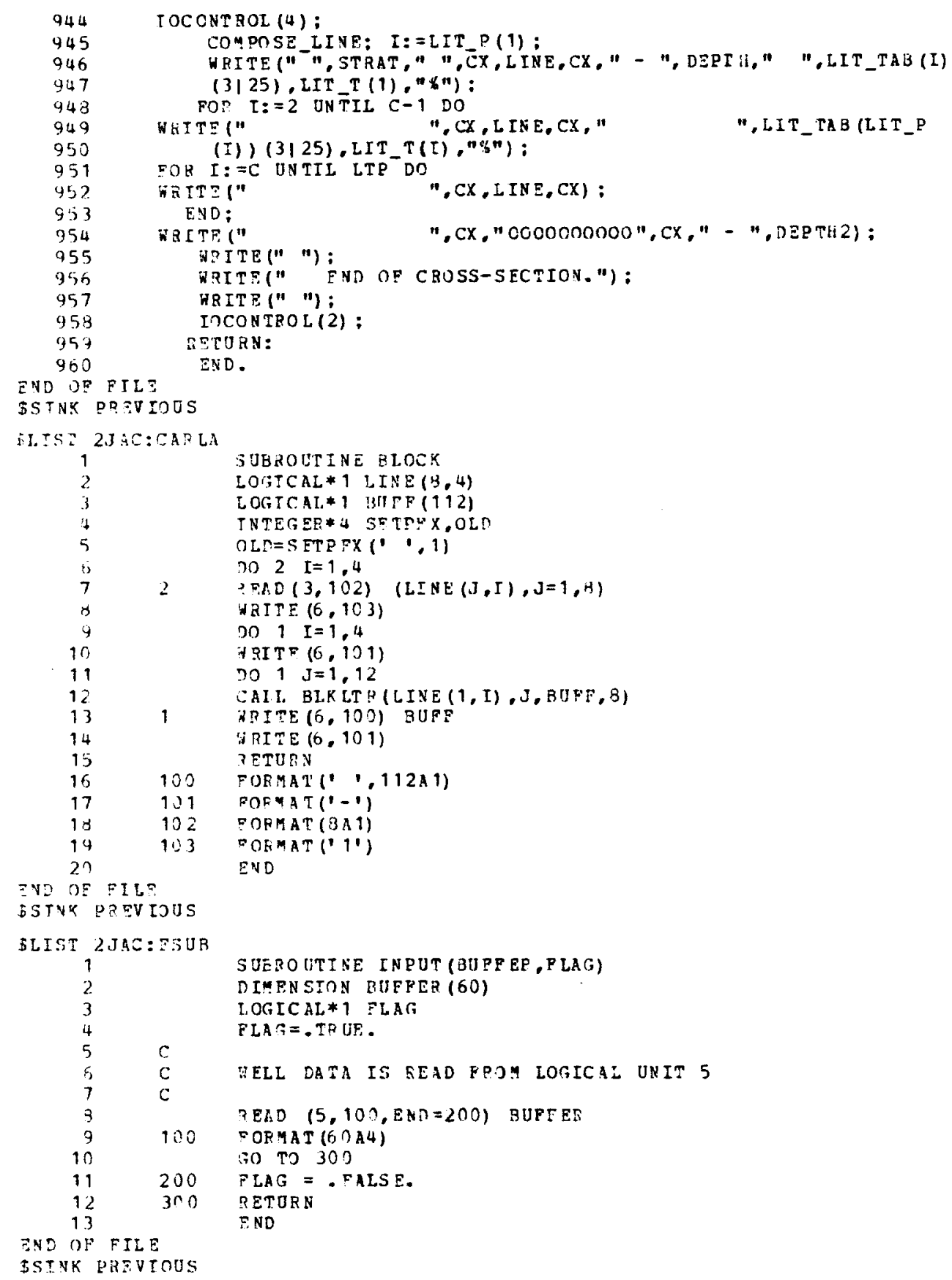




\section{APPENDIX III}

Appendix III contains the complete internal dictionary, worksheet format, and user instructions.

\section{Worksheet Format}

Definition codes

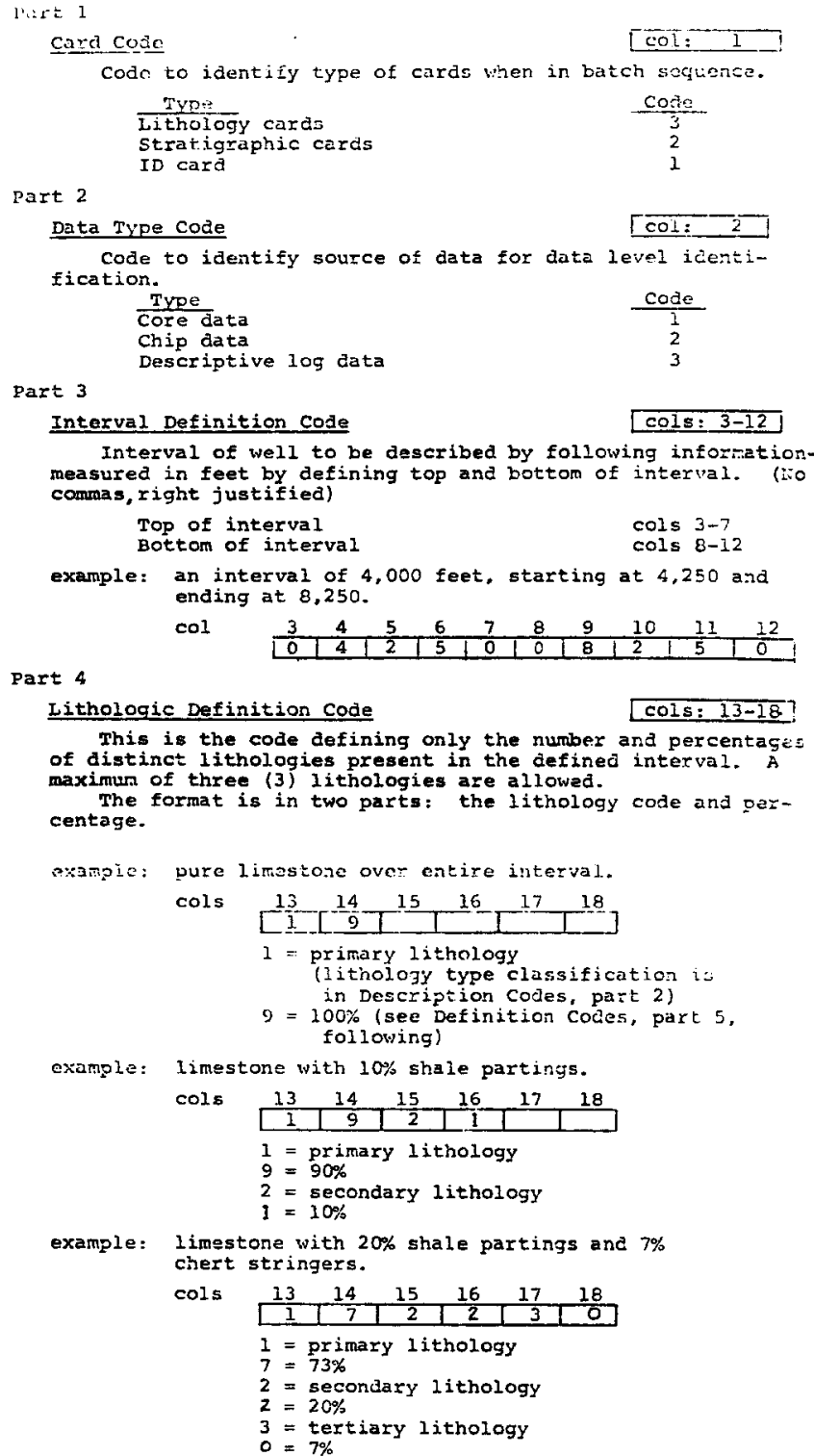

Interval of well to be described by following informationmeasured in feet by defining top and bottom of interval. (io comras, right justified)
Top of interval
$\operatorname{cols} 3+7$
$\operatorname{cols} 8-12$

example: an interval of 4,000 feet, starting at 4,250 and ending at 8,250

col

Part 4

Lithologic Definition code

This is the code defining only the number and percentages of distinct lithologies present in the defined interval. A maximus of three (3) lithologies are allowed.

The format is in two parts: the lithology code and oarcentage.

axanie: pure limestone over entire interval.

$$
\text { cols } \begin{array}{rl}
13 & 14 \\
1 & =\begin{array}{l}
\text { primary lithology } \\
\text { (1ithology type classification is }
\end{array} \\
& \text { in Description Codes, part 2) } \\
& =00 \% \text { (see Definition coces, part } 5,
\end{array}
$$

example: limestone with $10 \%$ shale partings.

$$
\text { cols } \begin{array}{rr|r|r|r|r|}
\hline 13 & 14 & 15 & 16 & 17 & 18 \\
\hline 1 & 9 & 2 & 1 & & \\
\hline
\end{array}
$$

$1=$ primary lithology$$
2=\text { secondary lithology }
$$

example: limestone with $20 \%$ shale partings and $7 \%$ chert stringers.

cols

$$
\begin{aligned}
& 1=\text { primary lithology } \\
& 7=73 \% \\
& 2=5 e \text { sondary lithology } \\
& 2=20 \% \\
& 3=\text { tertiary lithology } \\
& 0=7 \%
\end{aligned}
$$$$
\begin{array}{|l|r|r|r|r|r|}
13 & 14 & 15 & 16 & 17 & 16 \\
\hline 1 & 7 & 2 & 2 & 3 & 0 \\
\hline
\end{array}
$$

Part 5

Pexcentage code

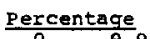

$0-9.9$

$20.0=29.9$

$30.0=39.9$

$40.0=49.9$

$50.0-59.9$

$60.0-69.9$

$70.0-79.9$

$80.0-89.9$

$90.0-100.0$

not specified

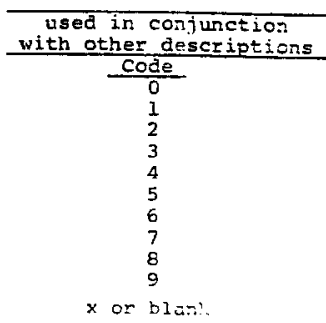

DESCRIPTIVE CODES

Part 1

Format for the Descriptive Section

The following section concern the codes for the description of lithologic components and their properties. Each subject is approached in the same manner. The 
The descriptive unit consints of three part:

1. Iithologic identification

2. property code

3. percentage.

expresed in four (4) colume on the data sheet.

one descriptive unit

The fixst column is for the lithologic identiflcation code (see Definttion Codes, part 4). The second and third columis are for the dencriptive code (ene following code listd And the fourth colum is for the percentage code (see Definition Codes, part 5 ).

oxample: some foseil spirifor brachiopods in the major 1ithology. the brachiopods comprieing $80 x$ of the foseil prosent.

\section{\begin{tabular}{l|l|l|l|}
\hline 1 & 4 & 4 & 8 \\
\hline
\end{tabular}}

$1=$ major lithology $-\operatorname{col} 2$ of dewcriptive unit $44=$ pirifor brachiopod - cols 2 of of descriptive unit
8 - BOX code

Part 2

Ithologic Description code

Cols: 19-34:

This section describes the lithology (rock name) for the 1ithologic component:. Porcentage and Iithologic component ax as previonsly defined. Four (4) maximum dencriptive unite are
allowed.

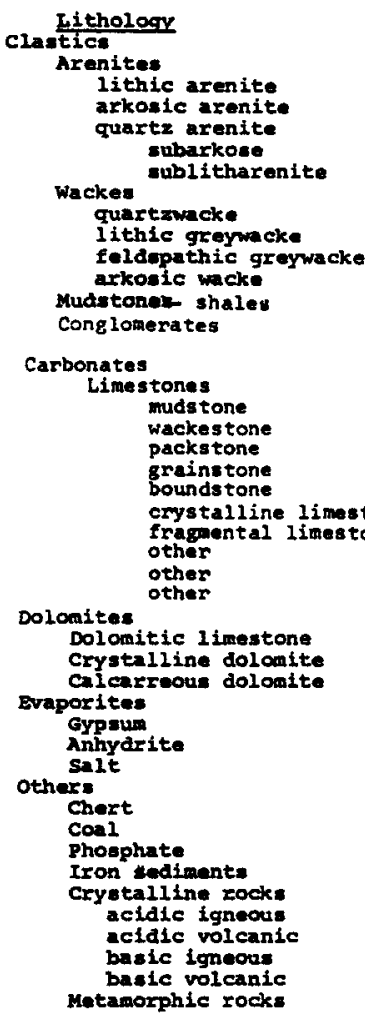

ublitharenit

quartzwack

lithic greywek

detonez- shale

stones

wackestone

rainstone

Cystalline limestone

other

other

Dolomitic imeston

Part 3

Color and tue Dancription code

Tho color and description of hue do not conform to the descriptive unit format. Instead it in a two part code. column 31 refers to color (see code list following discussion)
$x$
colar

column 32 refere to hue (aee code list following discussion)
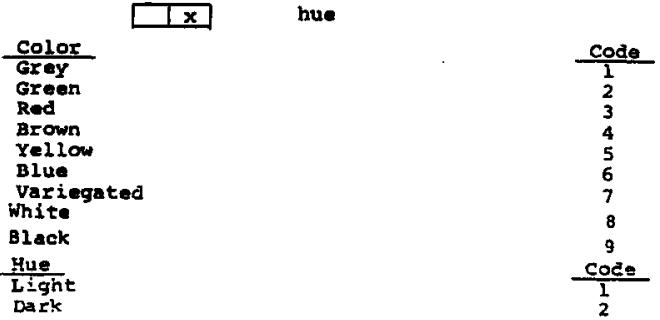
Part 4

Textura2 Description Code

Cols: 37-52

This section describes textures in lithologic sub-unite

by type and percentage. Four (4) descriptive unita are allowed for textures.

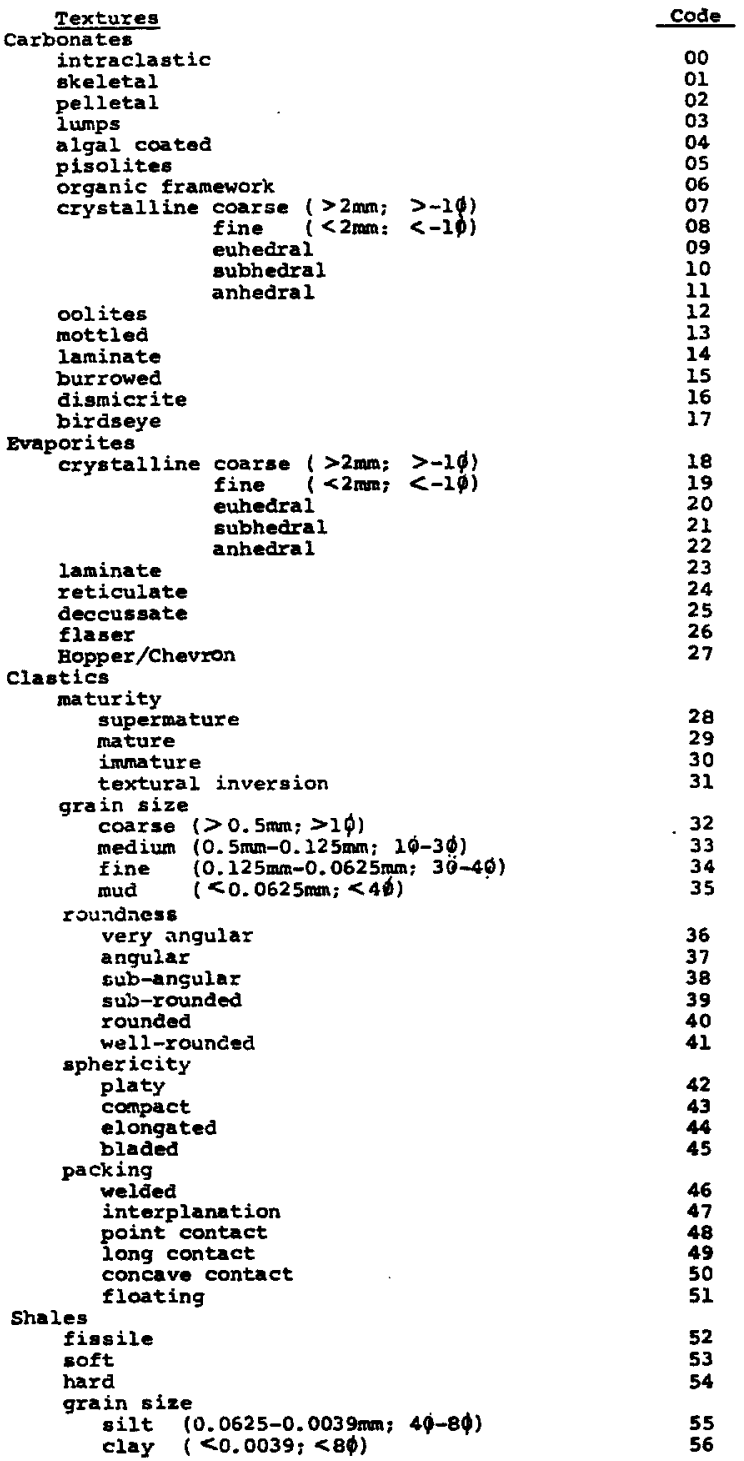

Part 5

Fossil Description Code

Cols: 53-108

The following is the descriptive list for foneil typen.

The symbol N/s represents not specified. The

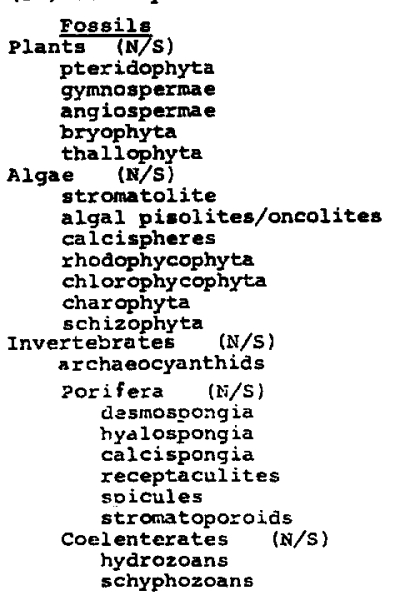

\begin{tabular}{c} 
cade \\
\hline 0 \\
1 \\
2 \\
3 \\
4 \\
5 \\
6 \\
7 \\
8 \\
9 \\
10 \\
11 \\
12 \\
13 \\
14 \\
15 \\
15 \\
17 \\
18 \\
19 \\
20 \\
21 \\
22 \\
23 \\
24 \\
25 \\
\end{tabular}




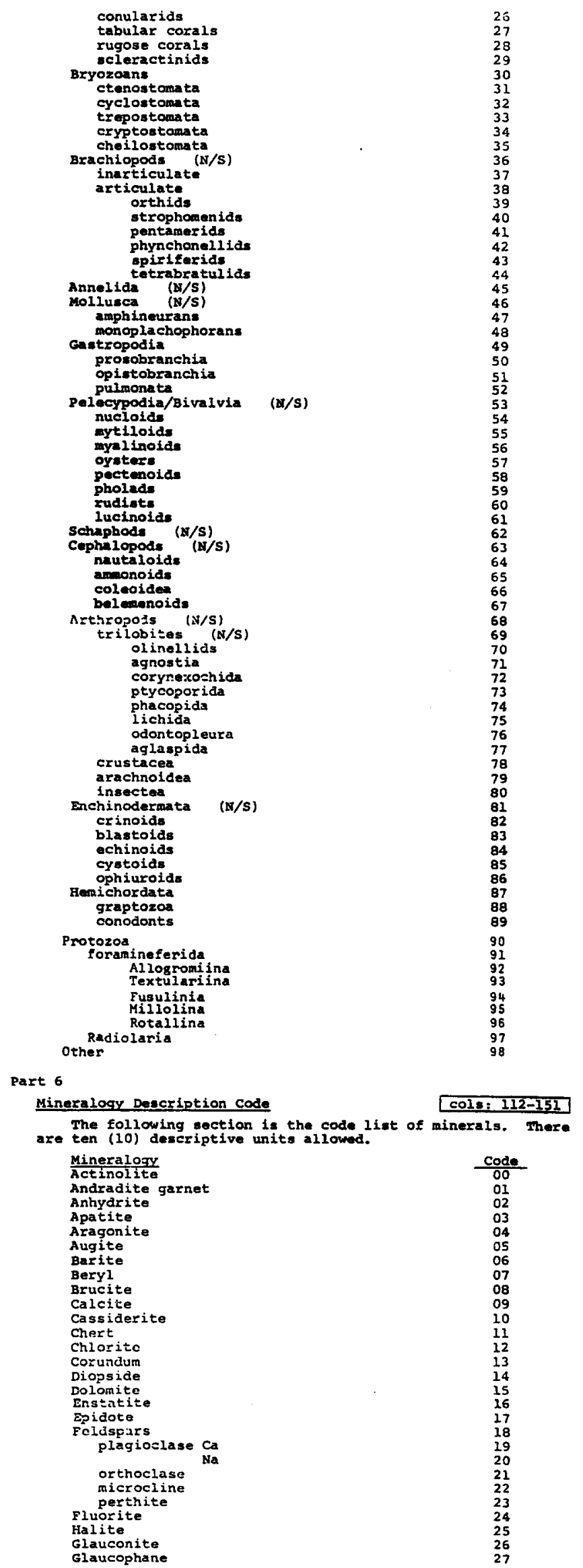


Grossularite garnet

Gypsum.

Hypersthene

Kyanite

Monozite
Olivine

Quartz

Riebicite

Rutile

Siderite

Silimanite

Sphalerite

Sphene

spinel

Sylvite

Topaz

Tourmaline

Trenolit

zircon

Other

Other

Other

Other

Other

Other

part 7

Sedimentary Structure code

c015: 152-171

The following in list of sedimentary structures. There

are five (5) descriptive units allowed.

Sedimentary structures

planar beddin

Laminations

Cross-bedding

Graded bedding

Varves

Linear bedding

Striations

Sani lineation

Casts

Current markings

Drag marks

Grouve \& groove casts

Bedding plane markings

have wash mark

Pits a prints

Scous

Ripple marks

sud cracks

Sole marks

para-ripole

Load cast

Flute

Deformed bedding

soft sediment deformation

clay balls

Distributed bedding

Sedimentary sills

Convoluted lamination

veins

Slump

Huderacks

structureless

Borings

Tracks \& trails

Cast o molds

Pellets

coprolites

Burrows

Breccia

fault

sol

vertical

angle - high $\left(>45^{\circ}\right)$

\begin{tabular}{c} 
Code \\
\hline 00 \\
01 \\
02 \\
03 \\
04 \\
05 \\
06 \\
07 \\
08 \\
09 \\
10 \\
11 \\
12 \\
13 \\
14 \\
15 \\
16 \\
17 \\
18 \\
19 \\
20 \\
21 \\
22 \\
23 \\
24 \\
25 \\
26 \\
27 \\
28 \\
29 \\
30 \\
31 \\
32 \\
33 \\
34 \\
35 \\
36 \\
37 \\
38 \\
39 \\
40 \\
41 \\
42 \\
43 \\
44 \\
45 \\
46 \\
47 \\
\end{tabular}

Part 8

Diagenetic Description Code

Co1s: 172-19]

The following is a list of diagendic features. Ther

are five (5) descriptive units allowed. Diagenesis

carbonates

Solution structures (N/S)

Styolites

corrosion zone

Vugs

crystal lined

salt plugged

Pisoites

vadose weathering

Mottling

001 iclists

Stromatactis

Neonozphism (recrystalization)

Replacamant dolonitization

Pervasive dolonitization

\begin{tabular}{c} 
code \\
\hline 00 \\
01 \\
02 \\
03 \\
04 \\
05 \\
06 \\
07 \\
08 \\
05 \\
10 \\
11 \\
12 \\
13 \\
14 \\
15
\end{tabular}




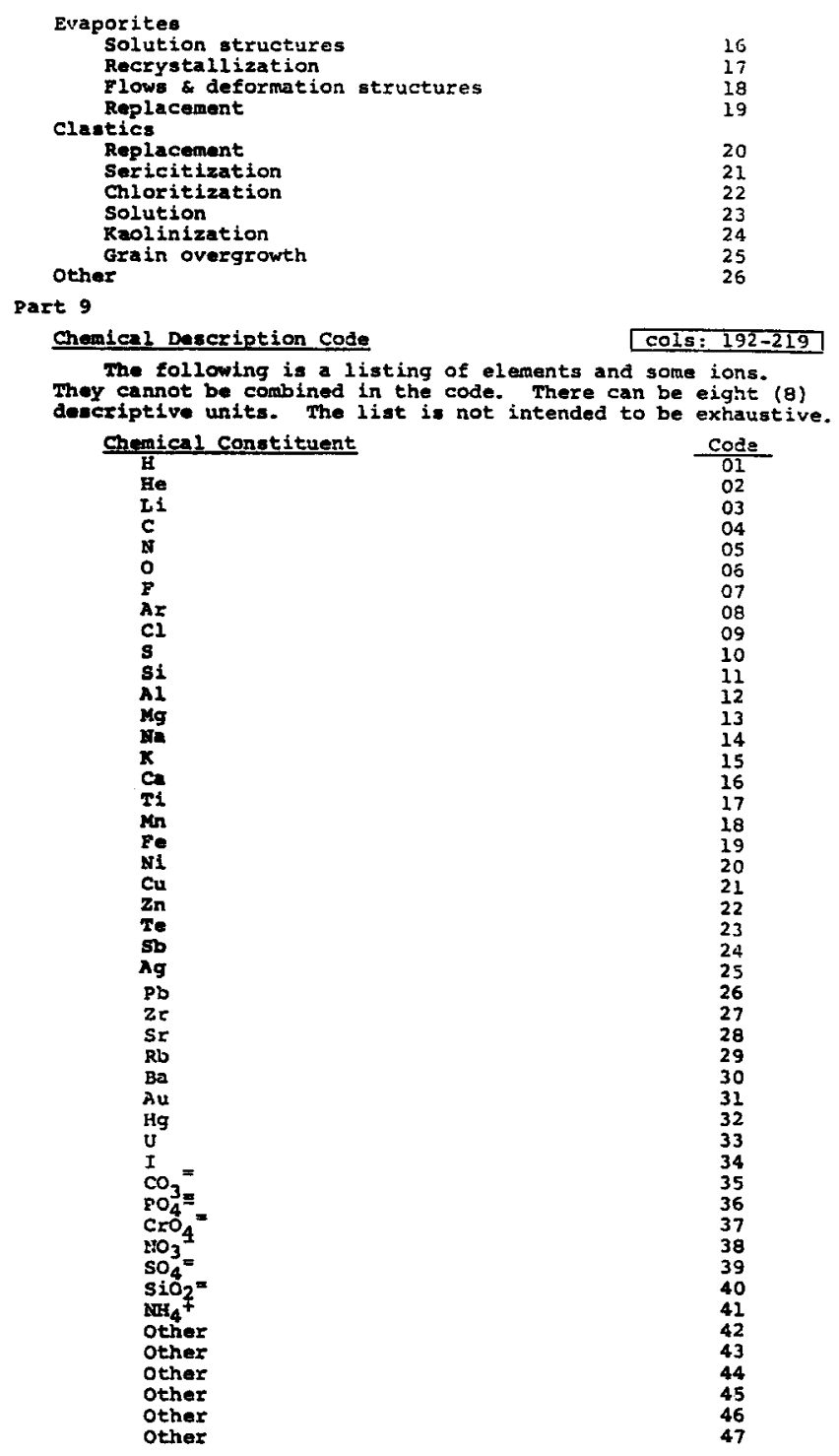

part 10

Bydrocarbon Description

cols: 220-227

The following is a brief listing of petroleun and gas occurrences. There is roo
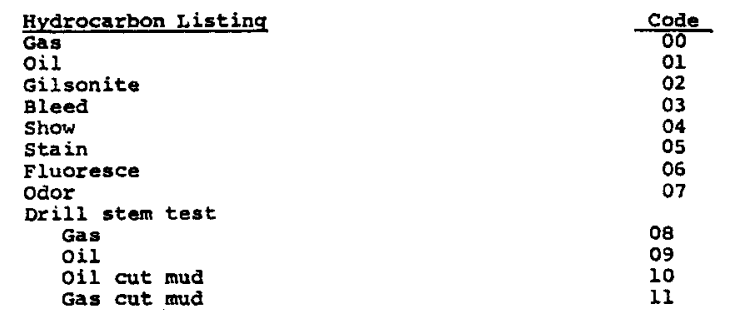

part 11

Porosity Description

The following is a classification of porosity. The classi fication is in two parts: type and size. The descriptive unit
changes to allow for the type and size as follows lst colurn - lithology identification as before (see

2nd column - porosity type (see list following discussion)

$3 r d$ colum - porosity size (see list following discussion) 
4th column - percentage code (see Definition Codes, part 5)

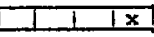

example: $27 \%$ megayugular porosity in primary lithology. \begin{tabular}{|l|l|l|l|}
\hline $1 / 8|1| 2$ \\
\hline
\end{tabular}

1 = primary lithology

$$
\begin{aligned}
& 1=\text { mega } \\
& 2=27 \% \text { code }
\end{aligned}
$$

Porosity Description

iny eype

interparticl

intraparticl.

intercrystal

molaic

fenestral

growth-framowor

vactoria

vag/channol/caver

porosity size

megrpore (4man-256m)

micropore $(<1 / 16 \mathrm{~mm})$

Coae

$p a x t 2$

Pesreability Dsscription code

The permeability description does not conform to the

descriptive unit format. The permeability in milldercys is

deciral point between colunns 239 sid

decimal point between columns 239 and 240 (measurement to

tenths). If measurement is not that accurate, anter a zero

example: permeability of $27.5 \mathrm{md}$

cols \begin{tabular}{r|r|r|r|r|r|}
236 & 237 & 238 & 239 & 240 \\
\hline 0 & 0 & 2 & 7 & 5 \\
\hline
\end{tabular}

example: permeability of $260 \mathrm{md}$.

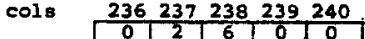

\begin{tabular}{|c|c|c|c|}
\hline Syziem & Code & Series & Code \\
\hline Owaternary & 700 & $\begin{array}{l}\text { Recont } \\
\text { Peistocene } \\
\text { Pliocene } \\
\text { Miocene } \\
\text { Oligocene } \\
\text { Eocose } \\
\text { Pailececene }\end{array}$ & $\begin{array}{l}702 \\
701 \\
705 \\
704 \\
653 \\
652 \\
651\end{array}$ \\
\hline $\begin{array}{l}\text { Cretaceous } \\
\text { Jurasuic } \\
\text { Trisstic }\end{array}$ & $\begin{array}{l}\mathbf{6 0 0} \\
550 \\
500\end{array}$ & $\begin{array}{l}\text { Upmer } \\
\text { Middle } \\
\text { Lomer }\end{array}$ & $\begin{array}{l}503 \\
502 \\
501\end{array}$ \\
\hline $\begin{array}{l}\text { Permian } \\
\text { Permo-Carbonifetrous } \\
\text { Pennsylvanian }\end{array}$ & $\begin{array}{l}450 \\
110 \\
400\end{array}$ & $\begin{array}{l}\text { Coneniaugh } \\
\text { Pottsville }\end{array}$ & $\begin{array}{l}405 \\
402\end{array}$ \\
\hline Missiessppian & 364 & $\begin{array}{l}\text { Potssile } \\
\text { Chesteriun } \\
\text { Mersmecian } \\
\text { Osagian } \\
\text { Kinderhoukian }\end{array}$ & $\begin{array}{l}302 \\
354 \\
353 \\
352 \\
351\end{array}$ \\
\hline $\begin{array}{l}\text { Mississipian-Devonian } \\
\text { Deronian }\end{array}$ & $\begin{array}{l}310 \\
300\end{array}$ & $\begin{array}{l}\text { Brathordian } \\
\text { Chiliugugquan } \\
\text { Senetur } \\
\text { Erran } \\
\text { Ulsterian }\end{array}$ & $\begin{array}{l}305 \\
304 \\
30.3 \\
302 \\
301\end{array}$ \\
\hline Silurian & 250 & $\begin{array}{l}\text { Cisyugan } \\
\text { Nizgtran } \\
\text { Albion or Alkzandrian }\end{array}$ & $\begin{array}{l}253 \\
252 \\
251\end{array}$ \\
\hline Ordovician & 200 & $\begin{array}{l}\text { Cincinnatian } \\
\text { Champlaınian } \\
\text { Canadian }\end{array}$ & $\begin{array}{l}203 \\
202 \\
201\end{array}$ \\
\hline Cambrian & 150 & $\begin{array}{l}\text { Croixian } \\
\text { Albertian } \\
\text { Wizucoban }\end{array}$ & $\begin{array}{l}153 \\
152 \\
151\end{array}$ \\
\hline Precambrian & 100 & & \\
\hline
\end{tabular}

STRATIGRAPHIC CODES FOR THE MICHIGAN BASIN

(from Briggs and Briggs, 1974) 